\title{
Thermal Reflex Sweating in Normal and Paraplegic Man
}

\author{
Russell C. Seckendorf
}

Loyola University Chicago

Follow this and additional works at: https://ecommons.luc.edu/luc_diss

Part of the Medicine and Health Sciences Commons

\section{Recommended Citation}

Seckendorf, Russell C., "Thermal Reflex Sweating in Normal and Paraplegic Man" (1959). Dissertations. 559.

https://ecommons.luc.edu/luc_diss/559

This Dissertation is brought to you for free and open access by the Theses and Dissertations at Loyola eCommons. It has been accepted for inclusion in Dissertations by an authorized administrator of Loyola eCommons. For more information, please contact ecommons@luc.edu. (c) (i) $\Theta \Theta$

This work is licensed under a Creative Commons Attribution-Noncommercial-No Derivative Works 3.0 License. Copyright (c) 1959 Russell C. Seckendorf 
Thermal Reflex Swerting

in Normal and Paraplagic Man

By

Russell C. Seckendorf

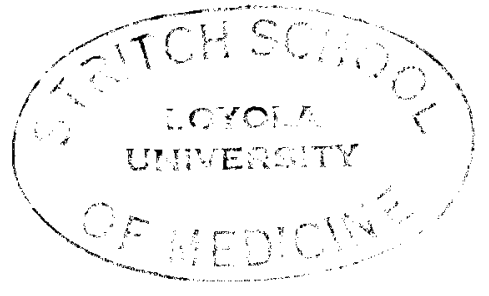

A Dissertation Submitted to the

Faculty of the Graduate School of

Loyola University in Partial

Fulfillment of the Requirements for

the Degree of Doctor of Philosophy

Februery

1959 
TABLE OF CONTENTS

Acknowledgnents ...................... il Blography ........................... ili Introduction ........................ 1

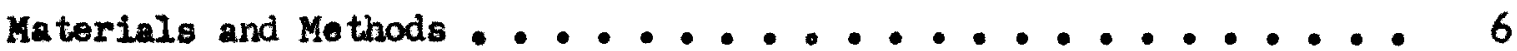

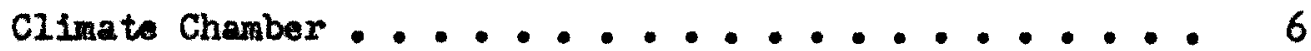

Methods of Recording Sweating Responses ........99

Methods of Temperature Measurement ......... 12

Experimental Procedure ............ 13

Experimental Results .................. 17

Patterns of Sweat Recrultment in Normal Man ...... 17

Observations on Oral and Rectal Temperatures of Normal Man ............. 31

Pattorns of Sweat Recruitment in Paraplegic Man .... 32

Skin Temperatures of Normal Man .......... 37

Skin Temperatures of Paraplegic Man ......... 40

Discusaion and Conclusions ....................... Sumary ... . . . . . . . . . . . . . . 49

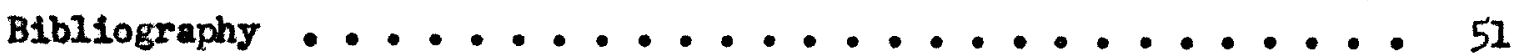




\section{ACKNOWLEDCMENTS}

The author wishes to express his deepest gratitudo to Dr. Walter C. Randall, Chairman of the Department of Physiology, who as a friend and advisor was a constant source of inspiration. His guidance, helpful criticiam, and sincere effort were of inestimable value in the preparation of this work.

The author also wishes to express his sincere appreciation to Dr. Clarence N. Peiss for his encouragenent and helpful suggestions.

Grateful acknowledgment is extended to Dr. Lewis J. Pollock and Dr. El1 L. TIgay of Hinog Veterans Administration Hospital for their cooperation in making the paraplegic phase of this study possible.

Sincere appreciation is extended to Messrs. Michael Blunk, Hobart Holloway, Henry Krzyudzinski, and Harold Mundin, patients at Hines Hospital, for their voluntary cooperation without which much of this work would not have been possible.

The author gratefully acknowledges the helpful technical assistance of the following: Mossrs. Thomas Akers, Lewrence Barnet, James Doyle, Kohammed Duheidal, Anthony Garruto, Charles Pastika, Joseph Sinone, Constantine Tatooles, John Wall, Giles Zollar, Stanley Zydlo, and Miss Joan Bibelhausen. 


\section{BIOGRAPHY}

Russell Charles Seckendorf was born in Brooklyn, New York, on October 23, 1926. He received his elementary education in the public school system of Albany, New York and graduated from the Christian Brother's Academy of Albany in 1944.

The same year he enterod the United States Army in which he served for 27 months.

In 1946 he enrolled at Siena College in Londonville, New York. He pursued a courge of stady with a major in biology and a minor in chenistry. He was awarded Bachelor of Science degree in June 1949.

In September of the same year ho entereil a program of graduate study toward a degree of Master of Science in Physiology at St. Louls University in St. Louls, Missouri. He was awarded said degree in July 1951. He remained at this University until 1952.

In August of 1952 he moved to Philadelphia, Pennsylvania where he accepted a position as Instructor in Physiology at Temple Univeraity Dental School. Concurrentiy, he entered part-time program of graduate sudy in Physiology at Jefferson Medical College in Philadelphia. He continued in this dual capacity until March 1957. At that tine, ho mored to Chlcago to begin a program of study towards the degree of Doctor of Philosophy in Phyriology at Loyola University. To dato he has been fulfilling the requirements for this degree. 


\section{INTHONUCTTON}

A study of sweting rasponoes from rogional okin aroes in man has been made by sevaral imvestigators $(1,2,3,4,5)$. These otudios astabliahod the existence of reglonal differences in the aveating ratos. However, Randall $(6,7)$ we the firet to elueidato the pattorn of these reglonal differences. In his first Investigntion of the problem (6) handall observed, during therwal equilibrium tudies with an amblent temperature just above the swosting threshold, that aweating was confinad to the most inferlor portions of the body. At higher amblent temperatures, sweating responses apread rostrally in an orderIy soquonce unt1l all areas oxhibitad oudomotor activity. In a dotalled analyeis of this phenomenon Rendall et al. $(7,8)$ establiobod thas when the entire body of bormin man is exposed to a progressive elevation of environmental temperature, thermal awoating is consiotentily cocruited first on the lowermost portions of the body (dorsum of the foot, celf) with progressive reorultant cephaled to ultimately Include all reglonal arvas. Randell ot al. (9) found thet the same genoral pattern of recrultwent obtained If only the upper pertion of the body was hoatod. These studies resutod the opinion that human sweating alwaye appears unfverselly over the entire body $(10,11)$.

AI though heating only half of the body surfece brings about recruitmont of sweating of all roglonal areas, It seened reasonable to assuse that hesting a 
very amall fraction of the body surface would not ellcit recruituant of all areas. Betwen these two fractions there probably exlsts a eritical cauntity of okin aurface that must be hented, to a iven levol over a particular time, before recrultment is complete. If ouch an hypothosit were valid, heating a subaninital area for any biven set of conditions would recruit no sweating or sweating on Iimited areas of the body.

It is an important function of these Investigations to test whe validity of this hypothesis and to study tho relationship betwen the area heated and the areas on which sweting 18 recrulted.

Examination of Fandall'g work (7) revalu that recrul tonent frequently started before a rise in body tamperature occurred and in many inatances whan body tempereture was falling. Randall was inclinad to tho opinton that the rearuftment of those audomotor responses was reiated to sensory stimulation by heat. It seamed unlikely that intiation of the reaponee by atso in hypothelamio temperature could occur concurrently with a fall in body temperature. According to prosent concepta, thermoregulatory swatine 18 frected in two ways: (1) blood at elovated temperatures perfuses the hypothularus and stimula tes themoregulatory centers, and (2) afferent nerve impulaes, arriving from peripheral receptors, activato the same centers. The operation of the first mechanism has been proved beyond doubt. Ranson and his associates $(12,13 * 24)$ demonstreted this runction of the hypothaiawus snd showed the thermolytic areas to be situated in the anterior portion (15). With the hypothalamus intaet, thermoregulatory oveating 18 wall mained in upite of experimental destruction of hither centers. Cilnical otudies in witch specifio 
lesions have been anatomically demonstrated offer further conclusive evidence $(16,17,18 \& 19)$. The efferent pathways through the lower brain stem and spinal cord to the sympathetic outflow are not clearly understood, al though several authors $(20,21 \& 22)$ have contributed to an anatomical description. Afferent pathways for reflex thermal sweating are not known. Neither have the peripheral sensory receptors been satisfactorily defined. Until recently the afferent receptor was considered to be the end organ of Ruffint (23) but this was primarily an assumption unsupported by facts. Weddell et al. $(24,25 \& 26)$ have shown that encapsulated endings are probably not those associated wth thermal reception and that the true sensory ending is probably unencapsulated. Also, it has been demonstrated that for any given aree the sensation of warmth and the onset of sweating are not related (9).

Although the anatomical nature and spatial position of the peripheral receptor is urknown, it is clear that afferent nerve impulses impinge upon the central nervous system and cause reflex sweating. Randall ot al. $(27,28)$ observed that if one limb is heated with its circulation occluded, reflex sweating occurs. This has been thoroughly confirmed by Isekuts et al. (29). Also, Kuno (30) found that cooling an extremity with its circulation occluded causes inhibition of sweat outbreak on other areas. Although these studies clearly demonstrate that reflex sweating occurs, they do not demonstrate the extent, or for that matter, the actual participation of the hypothalamus in reflex swea ting.

The recruitment patterns of Randall $(7,9)$ reveal cyclic activity of the sweat glands within a regional area as woll as cyclic response among the 
various sweating areas. The cycles on different areas may be in or out of phase. The process of recruitment is regular, and if it is controlled by the hypothalamus, one must imagine a system in which the hypothalanus discharges differentially to each of the separate cutaneous areas. On the other hand, mediation of thermoregulatory sweating could occur at spinal levels through facilitation by sensory impulses impinging upon them from peripheral receptors. Variations in threshold of spinal centers would account for the successive recruitment.

Classical teaching has held, however, that hypothalamic influence is necessary for thermal sweating to occur $(31,32 \& 33)$, and several workers $(34,35,36,37 \& 38)$ have reported that in paraplogia thermal reflex sweating does not occur below the level of spinal transection. This level is not that of the structurel infury to the cord, but rather that lowermost postganglionic sympathetic comection with uninjured proximal portion of the central nervous system. The early and outetanding contributions of Head and Riddoch (34) are often quoted in support of the concept that thermoregulatory sweating does not occur on those areas served by the isolated spinal cord. However, this work did not involve critical observations of the thermoregulatory responses. Moreorer, all of the patients studied were in a debilitated state and none had recovered from the post-shock state of hyper-reflexia.

Relatively recent workers $(35,36,37 \& 38)$ have reinforced the concept that thernoregulatory sweating does not occur below the level of transection. All of these later investigators studied paraplegics who had completely recovered from the generalized mass reflex response as well as chronic hyper- 
reflexia. They all used either the quinazarin test of Gutiman (39) or the starch-iodine technique of Minor (40).

It is well recognized that reflex sweating may occur below the level of the lesion in paraplegia during the mass reflex and under conditions of visceral stimulation such 29 bladder or rectal distention (34, 4I \& 42). Since such visceral reflex sweating does occur, it is obvious that the spinal cord is capable of mediating a sweating reflex and that the efferent limb of the reflex arc, as well as the sweat glands, are capable of functioning. Also, it seems reasonable that the afferent limb of the thermal sweating reflex is intact. It appears then, that all of the necessary components for thermal spinal reflex sweating are present. It was felt that the inability of previous investigators to demonstrate such sweating was due to an inadequate stimulus or improper recording techniques.

A careful and thorough study of thermal sweating in paraplegic patients comprises an important portion of the current 8 tudy. 
MATERIALS AND METHODS

\section{Climate Chamber}

In all studies a climate chamber was employed that permitted control of environmental temperature between $18^{\circ}$ and $70^{\circ} \mathrm{C}$. The chamber was approximately 8 feot long, 6 feet wide, and 7 feet high. The door, walls and ceiling wero constructed of a double layer of $\frac{1}{3}$ inch wall board separated by a 1 inch air space. To obviate the necessity of opening the door during an experiment, two

6 inch square rubber dam "portholes" with slits in their centers enabled material to be passed into or out of the chamber.

A General Electric Thinline alr conditioner was mounted in one wall of the chamber enabling a decroase in temperature to $18^{\circ} \mathrm{C}$. This was an advantage on days when the ambient temperature was above the threshold level for sweating. On such days, the cooling procedure was applied only to the subject completely enclosed in the chamber in order to establish a zero base line for aweating.

The temperature within the chamber was elevated by means of a thermoatatically controlled heating unit mounted in one wall. Adequate circulation of the warm air without excessive convection currents was accomplished by 2 built in fan. Temperatures as high as $70^{\circ} \mathrm{C}$ were usually reached within approximately $2 \frac{1}{2}$ hours. Experimental time periods greatly in excess of this were source of increasing discomfort for the subject who was obliged to re- 
main relatively quiet during the entire procedure.

In all studies, except those involving only one arm in the chamber, the subject reclined comfortably on a 28 inch $\times 76$ inch copper screen mesh bed. The chamber was modified to permit exposure of Iimited areas of the body to the ambient temperature wi thin the chamber. In one wall of the chamber were two insulated doors, one above the other. A framed rubber diaphragm was fitted about the body of the subject at a level which demarcated that portion of the body to be placed in the chamber. The bed was constructed to permit the subject to lie in relative comfort with the frame about his body. It was then wheeled through the opening until the frane of the diaphragm cane flush with the frame in the upper door. The two franes were then bolted together to make a tight seal. The lower compartment door was then closed, making a seal with the lower portions of the bed frame and the diaphragm. Thus, the inside of the chamber was completely sealed from the outside oven though only a portion of the subject lay within the chanber (Figure 1). The rubber diaphragms were individually fitted for each subject and for each portion of the body to wich they were applied.

The bed was not used in experiments involving only one arm in the chamber because of difficulty in application. In these studies the subject sat on a chair with one arm protruding through the diaphragm. 


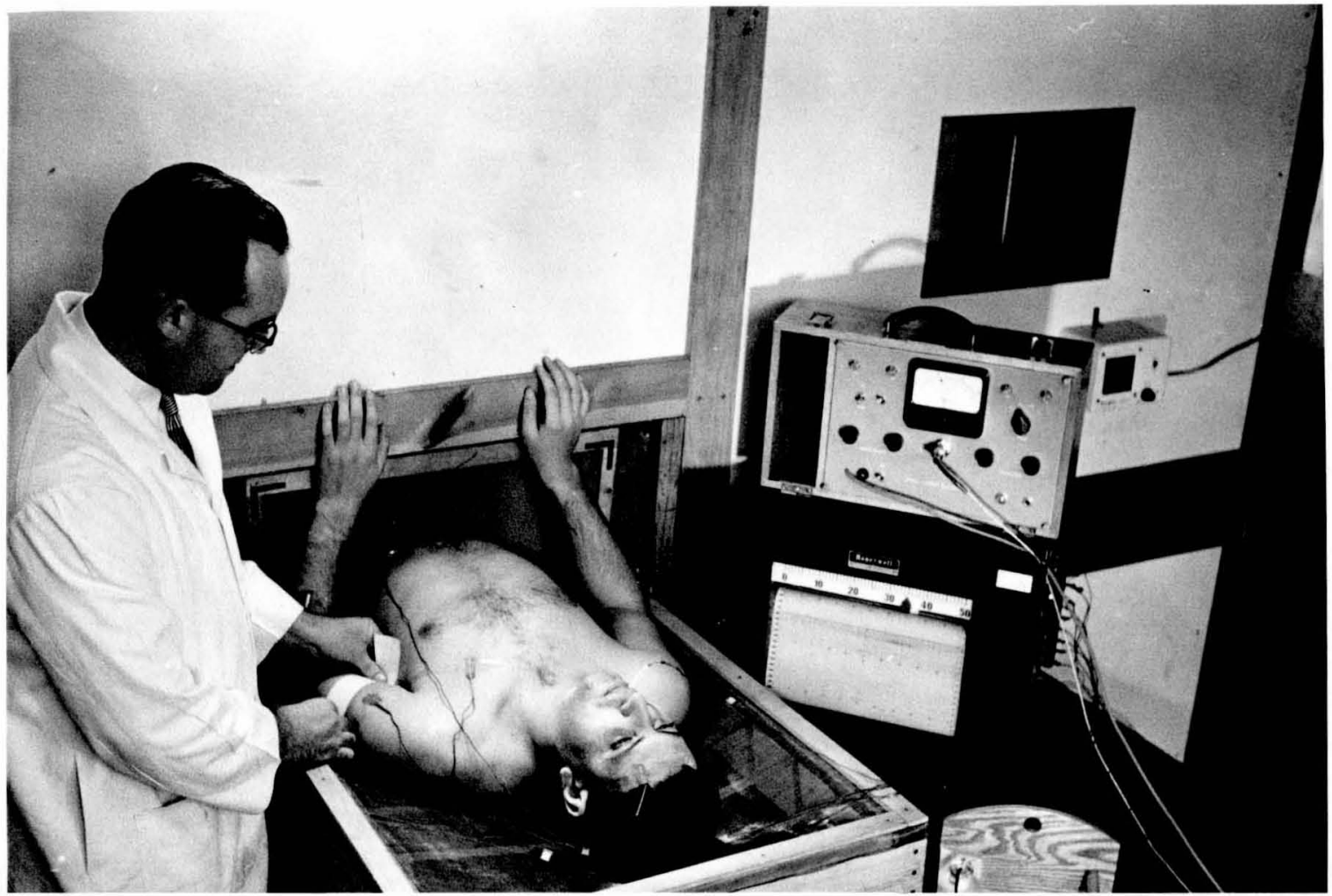

Figure I 
2. Me thods of Recording Sweating Responses

In the initial experiments, sweating responses were recorded by the technique of Randall (43). This method omployed a high starch content bond paper (e.g., Fox River Bond) which was applied to a skin area previously painted with a 3 per cent solution of lodine in 95 per cent ethyl alcohol. In the presence of sweat, reddish blue spots characteristic of the starch-iodine reaction appeared on the paper. This technique, al though extremely sensitive, presented two technical problems neither of which, however, affected the validity of the results. First, the starch-iodine spots were sensitive to light and in time faded and disappeared. In order to make the spots permanent it was necessary to undertake the tedious task of retouching them with ink. Second, the unretouched spots did not reproduce well on photographic paper. Thus, a new technique was developed in an effort to obviate these problems, particularly the former, and yet retain the high sensitivity of this well proven technique.

The new procedure consisted of applying paper, coated with palladium chloride, to a skin surface previously painted with potassium lodide. In the presence of sweat, a precipitate of palladium lodide formed distinct dark brown spots on the paper.

The palladiun chloride used was as pure as is comercially available. A 1 per cent solution was used but, due to insoluble impurities, only the decanted supernatant obtained after centrifugation could be used. The solution was applied to the bond paper by means of large cotton applicators. The area of skin from which records were to be obtained was painted with 
a 40 per cent solution of potassium iodide in 50 per cent athyl alcohol and water. Potassium iodide is rather highly soluble in water but only slightly soluble in ethyl alcohol. The alcohol was added to make the solution more volatile and give it a lower surface tension. This resulted in a rapidly drying liquid film that left a thin evenly dispersed coating of potassium iodide crystals on the skin surface.

The spots of palladium iodide which are formed in the presence of sweat are permanent. However, during the application of the paper to the skin, a few small crystals of potassium iodide invariably adhere to the paper. Since the formation of the precipitete of palladium iodide requires the presence of water, a spot will not appear if sweat is not present at the point of contact of such a crystal. However, potassium lodide is somewhat hygroscoplc and if the recording papers remain in contact with a warm humid environment, these crystals will in time pick up enough molature to allow the formation of the palladium iodide precipitate. Spots may then appear on the papers which were not caused by sweat. In a summer environment of $90^{\circ} \mathrm{F}$, and 90 per cent relative humidity, these "false" spots sonotimes appeared in one hour. In the cooler months of the year, when the room temperature was lower and the absolute water content of the air was considerably less, the hygroscopic ability of the potassium iodide was apparently not great enough to bring about hydration of the crystals and the "false" spots did not appear. Recording slips have been stored in the latter environment for several months without the appearance of the "false" spots.

This fault in technique was detected during the latter part of the investi- 
gation. It was observed that recording slips which showed no spots at the time of experimentation did show some spots when the papers were graded a day or two 1ater. It was then deemed necessary to cover all the slips with a protective coating that would seal, after experimentation, the recording surface of the paper from the enviromental molsture. An effective seal was made by the application of a strip of Du Pont Mylar tape to the recording surface. This is a transparent pressure sensitive polyester tape similar in appearance to Scotch cellophane tape but wi th decided additional advantages. Over long periods of time, it will not dry out, discolor, become brittle, or lose its tack. Its moisture resistant properties prevented the formation of "false" spots even when the tape coated recording papers were exposed to steam.

In a series of mock experiments in which a rubber membrane was substituted for the skin surface, spots did not appear on the recording papers.

Considerable trial and error was necessary before this simple method of protecting the recording papers was devised. During the interim, the stadies were conducted with the aid of the starch-iodine technique. A comparison study of the two methods showed no essential difference in the sweat patterns recorded simultaneously from two adjacent skin areas. 
3. Kethods of Temperature Measurement

Skin temperatures in all studies were measured by means of a Brown Instrument Company contimuous thermocouple recorder. This apparatus consists of 16 copper-constantan thermocouples connected to potentiometric circuit. An automatic selector switch operating at 2 second intervals permitted the recording of all 16 thermocouples in 32 seconds. A permanent record was obtained on moving graph paper calibrated in $0.2^{\circ}$ intervals from $0^{\circ} \mathrm{C}$. to $50^{\circ} \mathrm{C}$. Specially designed oral and rectal thermocouples were also attached to this circuit. Amblent temperatures within the limits of the recorder were likewise measured in this manner. Ambient temperatures above $50^{\circ} \mathrm{C}$. were obtained with a mercury thermometer.

In several studies, concomitant with thermocouple recordings, the skin temperatures were measured with a Stoll-Hardy Radiometer (44). The heat sensitive elements of this instrument are 4 very small thermistors suitably connected in a wheats tone Bridge. Temperature readings in ${ }^{\circ} \mathrm{C}$. above or below ambient were read directly from meter scale on the instrument. Ambient temperature was recorded from an alumimum reference block against whtch the radiometer head was balanced before each temperature reading. 
4. Experimental Procedure

This study consisted of 63 experiments conducted on 10 normal and 4 paraplegic subjects. The paraplegic subjects studied had surgically verified anatomically complete spinal transections between the levels of $\mathrm{T}_{3}$ and $\mathrm{T}_{8}$. Subjects with transections below this level were not studied because it has been reported (45) that postganglionic sympathetic fibers to the legs may have some preganglionic connections as high as $T_{9}$.

All subjects reclined on the screen mesh bed for at least 45 mimutes prior to experimentation. All paraplegic subjects were protected from the screen raesh by a foam rubber mattress 4 inches thick. This was necessary to avoid any excessive pressure on skin areas below the level of the lesion. During this pre-experimentation period, the bed and subject were placed in the appropriate position. The "hot" functions of the thermocouples, mounted in plastic holders, were fastened to the regional skin areas with Scotch tape (Figure 2).

In most of the studies the same 8 representative regional skin areas were used for recordings. They were the following: the dorsum of the foot, calf, thigh, abdomen, chest, forearm, upper arm 1 and forehead. The calculations of DuBois et al. (46) (Table I) were used to determine the percentage of body surface area heated in the "minimal area" studies.

Sweat papers were placed on the painted areas for a period of 15 or 30 seconds at intervals of 2, 3 or 4 minutes (Figure 2). In studies in which the radiometer was used, a reading from each area was usually obtained at intervals

In these studies the upper arm refers to the area between the forearm and the shoulder. 


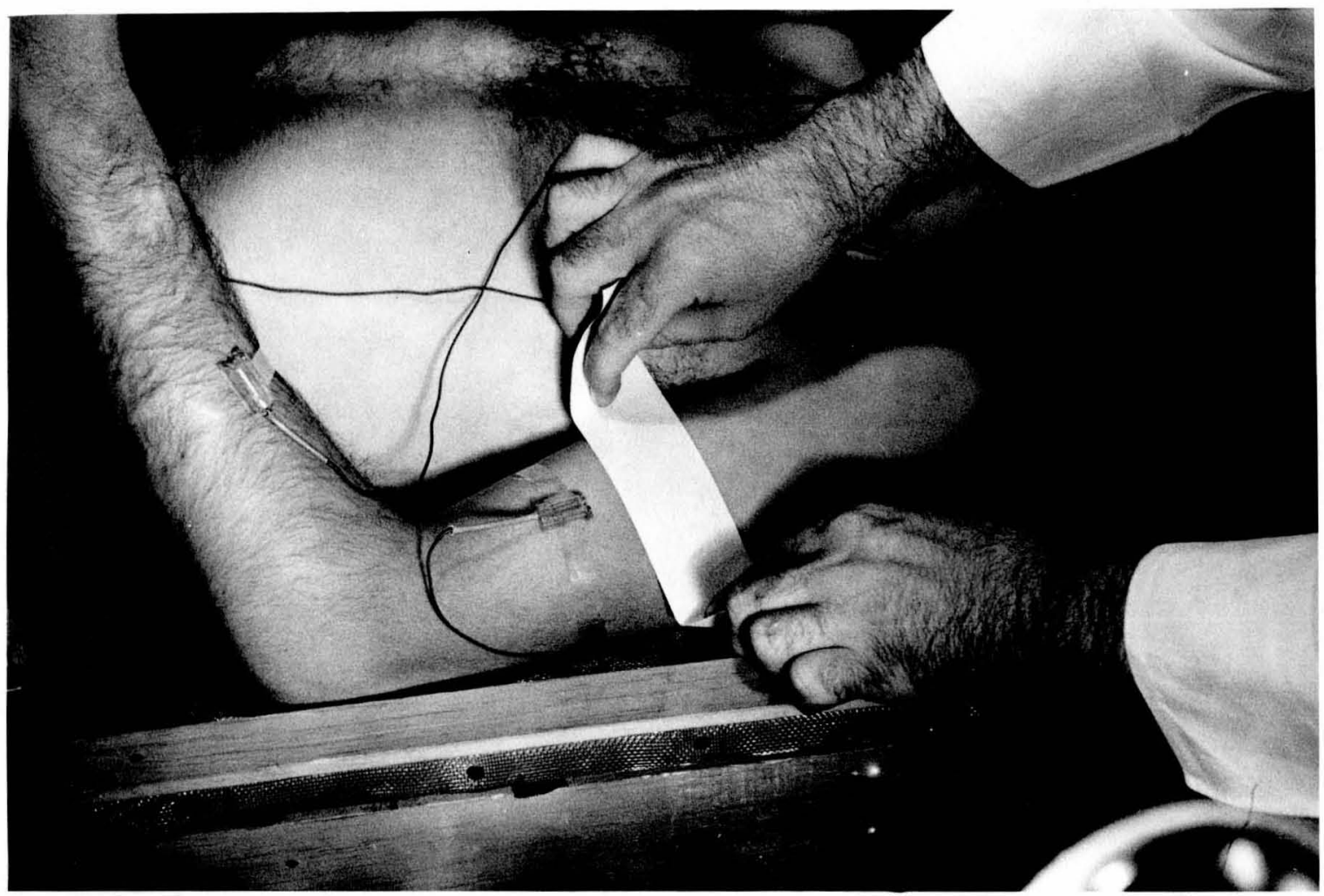

Figure 2 
TABLE I

Percentage of total body surface area

Head (not including neck)

Upper extrentities (excluding hands)

Hands

Foet

Legs

Thighs

Trunk (including neck)
7

14

5

7

13

19

35

\section{0}


of 8 to 10 minutes. The relative comfort of the normal subject was periodically checked to avoid any psychic influence from extreme discomfort. In the case of the paraplegic subject, the rectal or oral teraperature was closely observed as woll as his subjective sensations of comfort. It was desirable to avold an elevation in body temperature appreciably in excess of $1.50 \mathrm{C}$.

Before the conclusion of many experiments the chamber door was opened and the interior rapidly cooled. A fan was somotimes used to accelerate this cooling. 


\section{EXPERTMENTAL RESUL'S}

\section{Patterns of Sweat Recruitrent in Normal Man}

Figure 4 represents a "typical" pattern of successive craniad recruitment of regional areas when the entire body of normal man was exposed to a rising environmental temperature. As in all studies, the magnitude of the sweating responses was expressed in arbitrary units from a plus 1 to a plus 10 (Figure 3a). Although there were variations in the timing of recruitment from area to area in different experiments, the general patterns remained remarkably consistent. The lowermost portions of the body always exhibited sweating before the uppermost areas. A time lapse of 20-50 minutes commonly occurred between the appearance of sweat on the dorsum of the foot and its appearance on the forehead. The more rapid the rise in environmental temperature, the shorter the time interval required for recruitnent of all areas. The earliest swe ting rates could not be detected by visual observations of the skin but were marked and unmistakable when recorded by the palladium iodide or starch paper techniques. At ambient temperatures illustrated in Figure 4, a relatively profuse response was eventually seen on 211 areas. The sudden and dramatic decline in sweating was effected by opening the chamber door and cooling the interior as rapidly as possible.

A similar pattern of recruitment also obtained in nomal man when only the lower (Figure 5) or upper (Figure 6) portion of the body was heated in the 


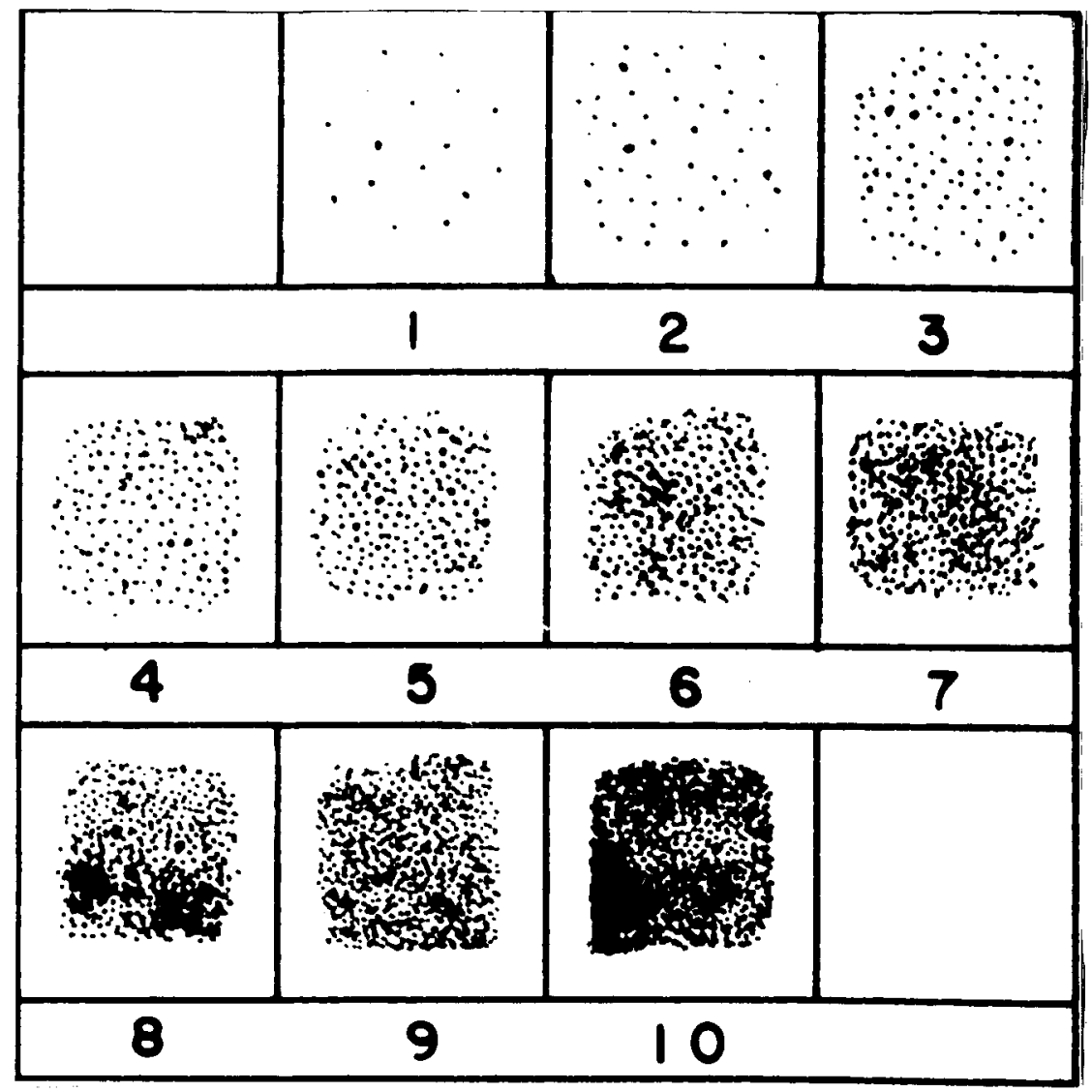

(a)

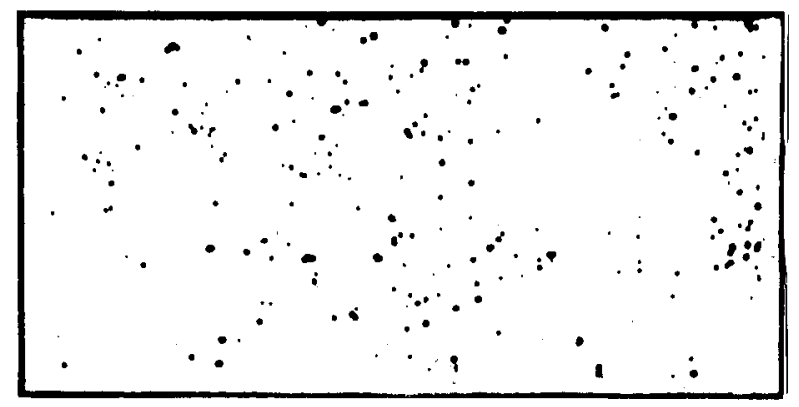

(b)

Figure 3 (a) Sweat intensity grading chart

(b) Plus 3 sweating response from dorsw of the foot of paraplegis patient 


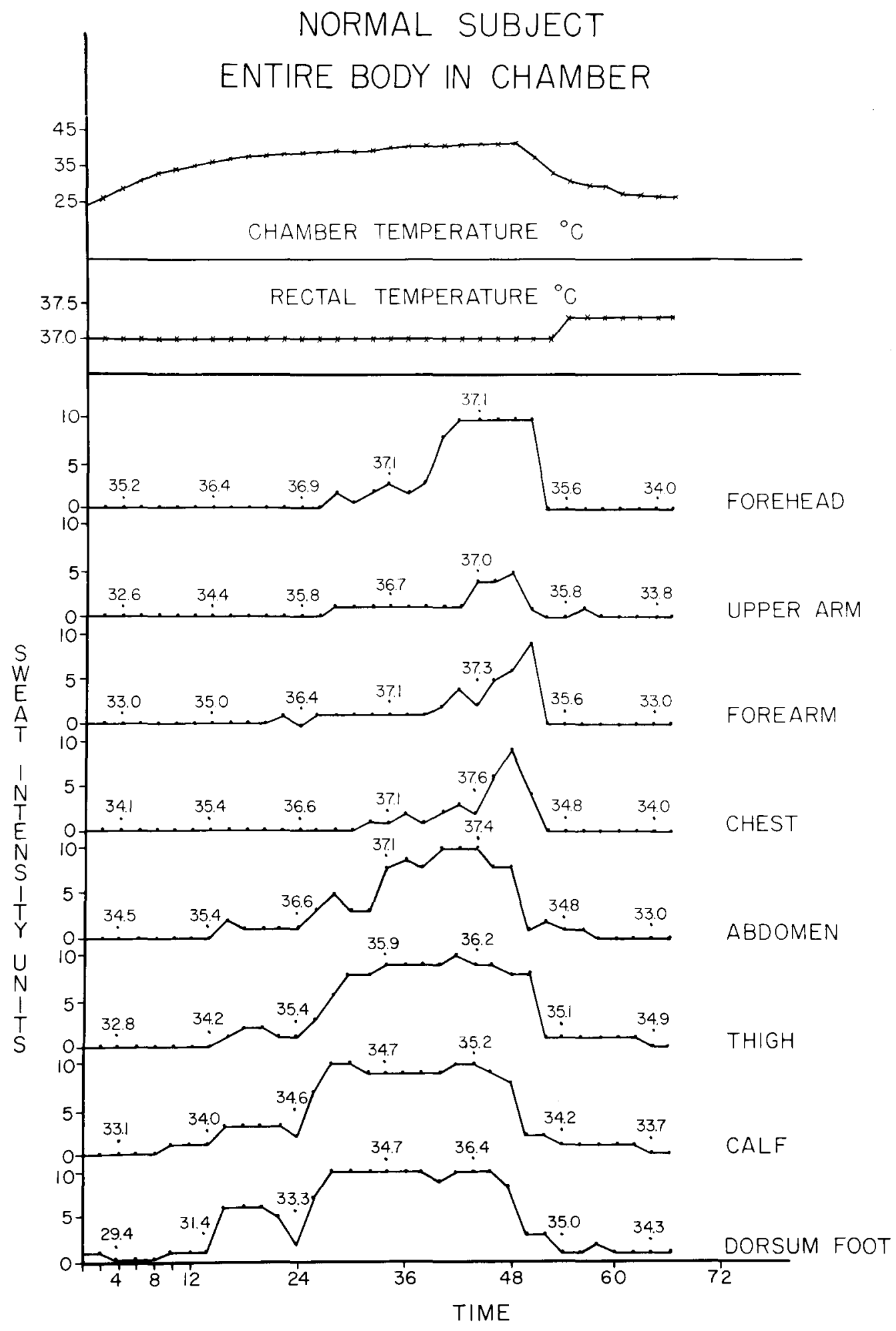

(2 MINUTE INTERVALS)

Figure 4 


\section{NORMAL SUBJECT}

LOWER HALF OF BODY IN CHAMBER

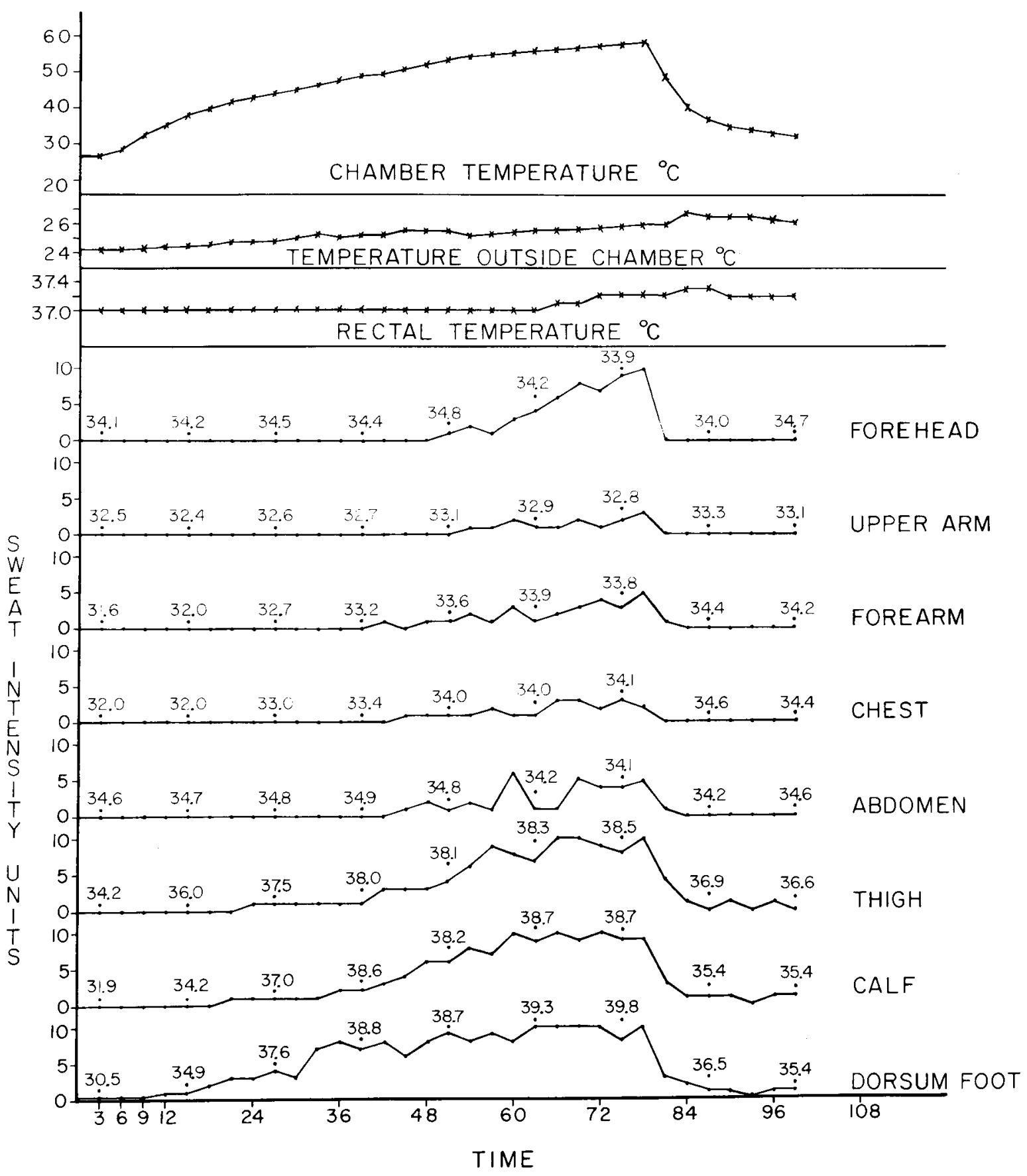

( 3 MINUTE INTERVALS)

Figure 5 
NORMAL SUBJECT

UPPER HALF OF BODY IN CHAMBER

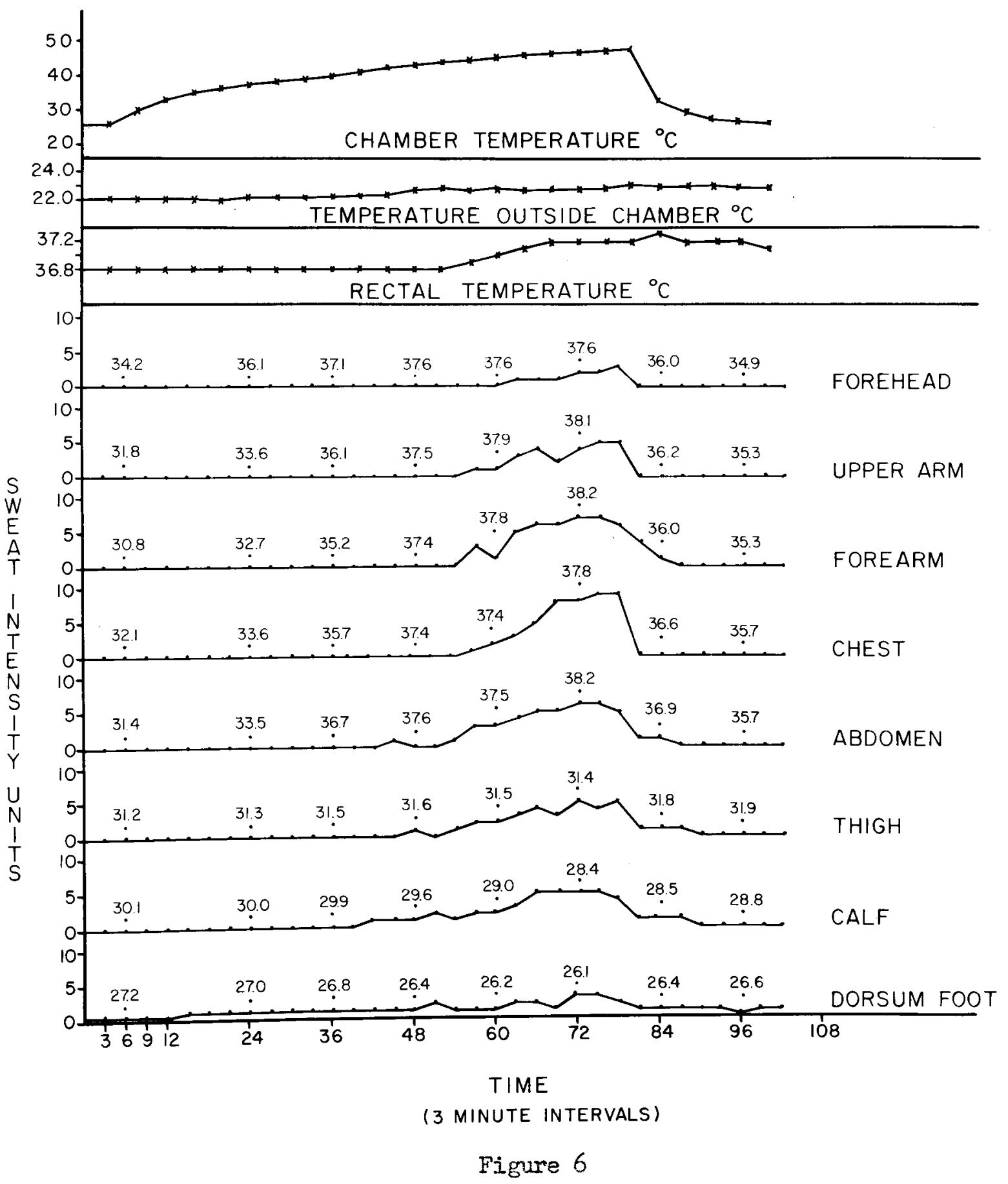


chamber. The level of the urabilicus was the dividing line between "in" and "out". In these studies it was nucessary to heat the portion of the body in the chamber for a longer period of time and to a higher temperature in order to recruit sweating on all areas. The magnitude of response was usually less on areas outside the chamber than on those inside the chamber. This was particularly true when only the lower portion of the body was heated (Figure 5). However, exceptions occurred and are illustrated by the forehead rasponees in Figures 5 and 6.

Figure 7 represents study with the normal subject seated outside the chamber with one upper extremity inserted into the chamber through the rubber diaphragm. Under these conditions an essentially normal pattern of recruitment invarlably obtained on all subjects. The magnitude of the sweating responses for all areas outside the chamber was less than in the studies with all or half of the body inside the chamber. In the experiment illustrated in Pigure 7 records of sweating were not made on the parts inside the chomber. When both feet of the normal subject were exposed in the heated chamber, a successive reoruitment of all areas again obtained (Figure 8). Vary high chamber temperatures were necessary to elicite such a response (over $60^{\circ} \mathrm{C}$ ), but in no instance was failure to recruit all areas encountered. Time intervals of an hour and a half or more were usually observed between the appearance of sweating on the dorsum of the foot and 1 ts appearance on the uppermost areas. Responses on all areas outside the chamber were of relatively low magnitude as compared to the studies that involved heating of larger surface areas (FIgures 5 and 6). This was not true for the areas being heated. Note 


\section{NORMAL SUBJECT}

\section{ENTIRE ARM IN CHAMBER}

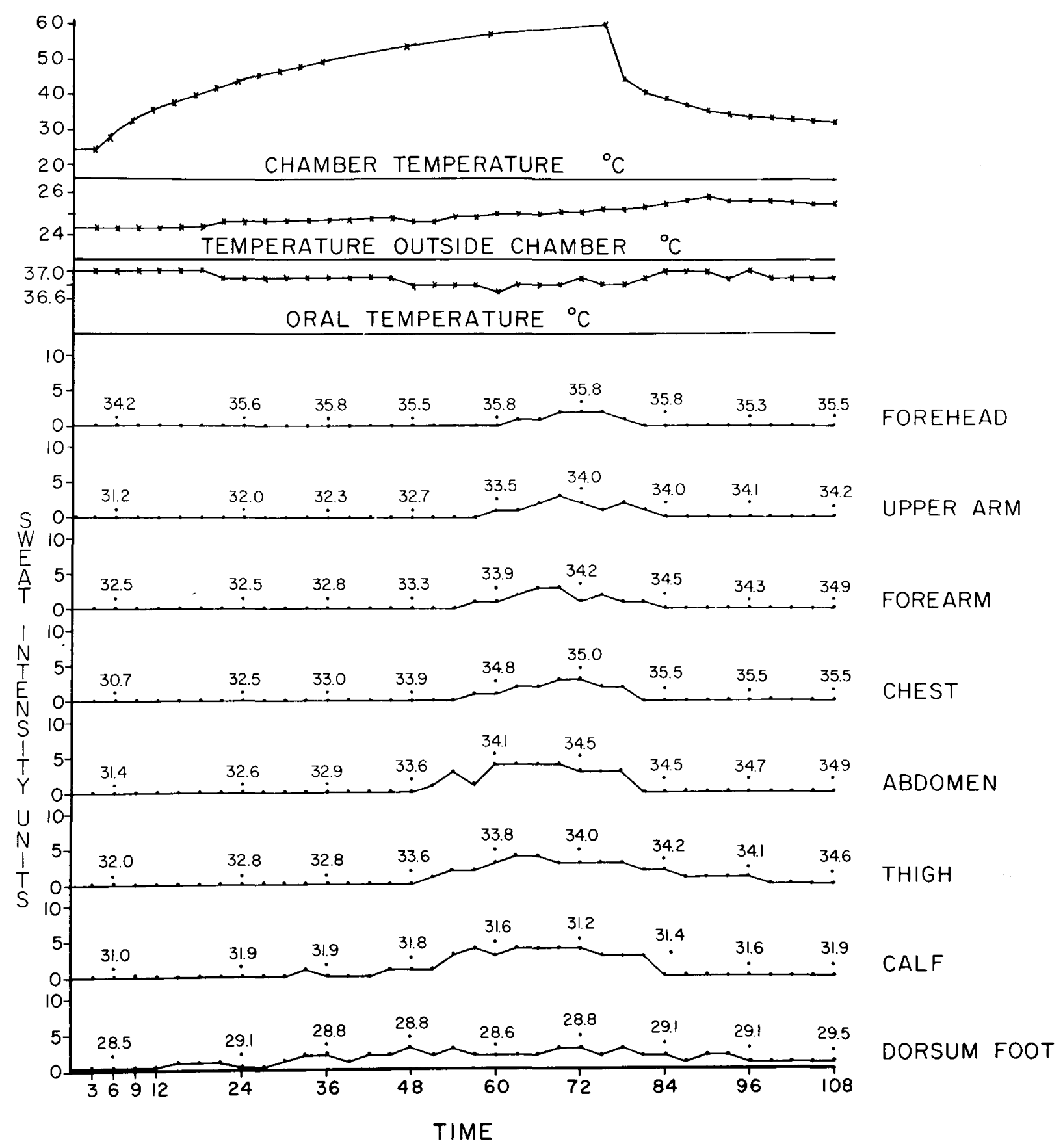

(3 MINUTE INTERVALS)

Figure 7 


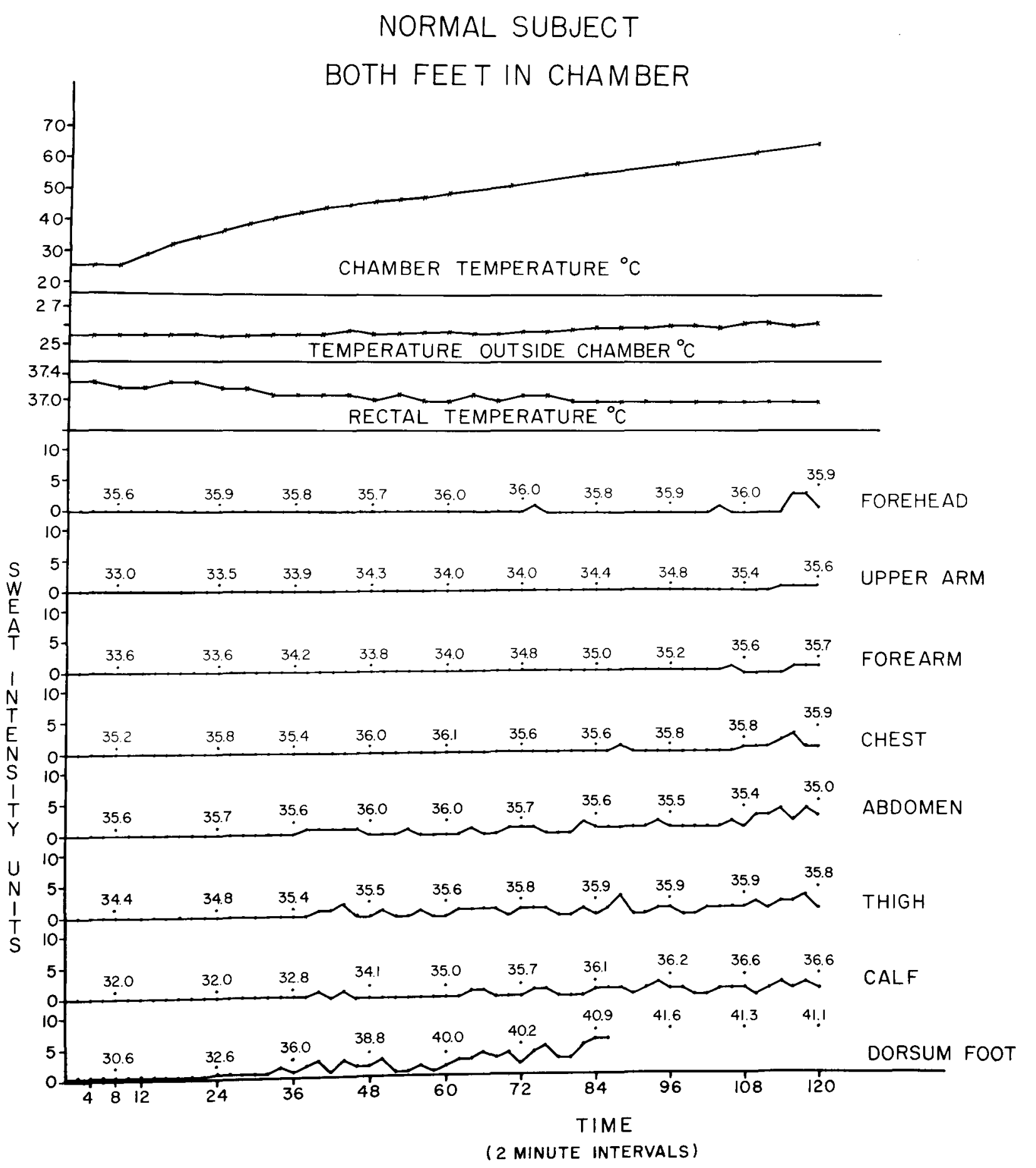

Figure 8 
the relatively high level of responee on the dorsum of the foot in Figure 8 . Recordings from this area were not made for the duration of the experiment because prolonged exposure to such very high temperatures became unbearable for the individual taking the recordings.

In a few experiments, occasional bursts of sweating appeared on the forehead before they were observed on the other upper areas.

Figure 9 exhibits data obtained in an experiment in wich only the head and a large portion of the subject's neck wore in the chamber. The head itself represents approximately 7 per cent of the body area and the entire neck another 2 or 3 per cent. Consequently, close to 9 per cent of the body surface area was exposed to heat. In this series of studios recruitment of all areas consistently required $208 s$ time and less heat than when both foet were exposed to the high temperatures. The "head in" studies exhibited results remarkably similar to the "arm in" studies.

It is especially interesting that aweating first appearod on the forehead 42 minutes after it had been recorded on the dorsum of the foot oven though only the head was exposed to the high ambient temperature. This is in significant contrast to the data illustratod in Figure 8 in wich sweating first appeared on the area warmed.

A atudy of the normal subject with one foot in the chamber is lilustrated in Figure 10. In this series, fallure to recruit sweating on all areas occurred for the firwt time. Exposing the foot to a progressive elevation in temperature up to $700 \mathrm{C}$. over period of $21 / 2$ hours failed to produce swoating above abdomen. In each of seven such experiments all areas up to and including the abdomen were recruited but in no instance was sweating observed on any 


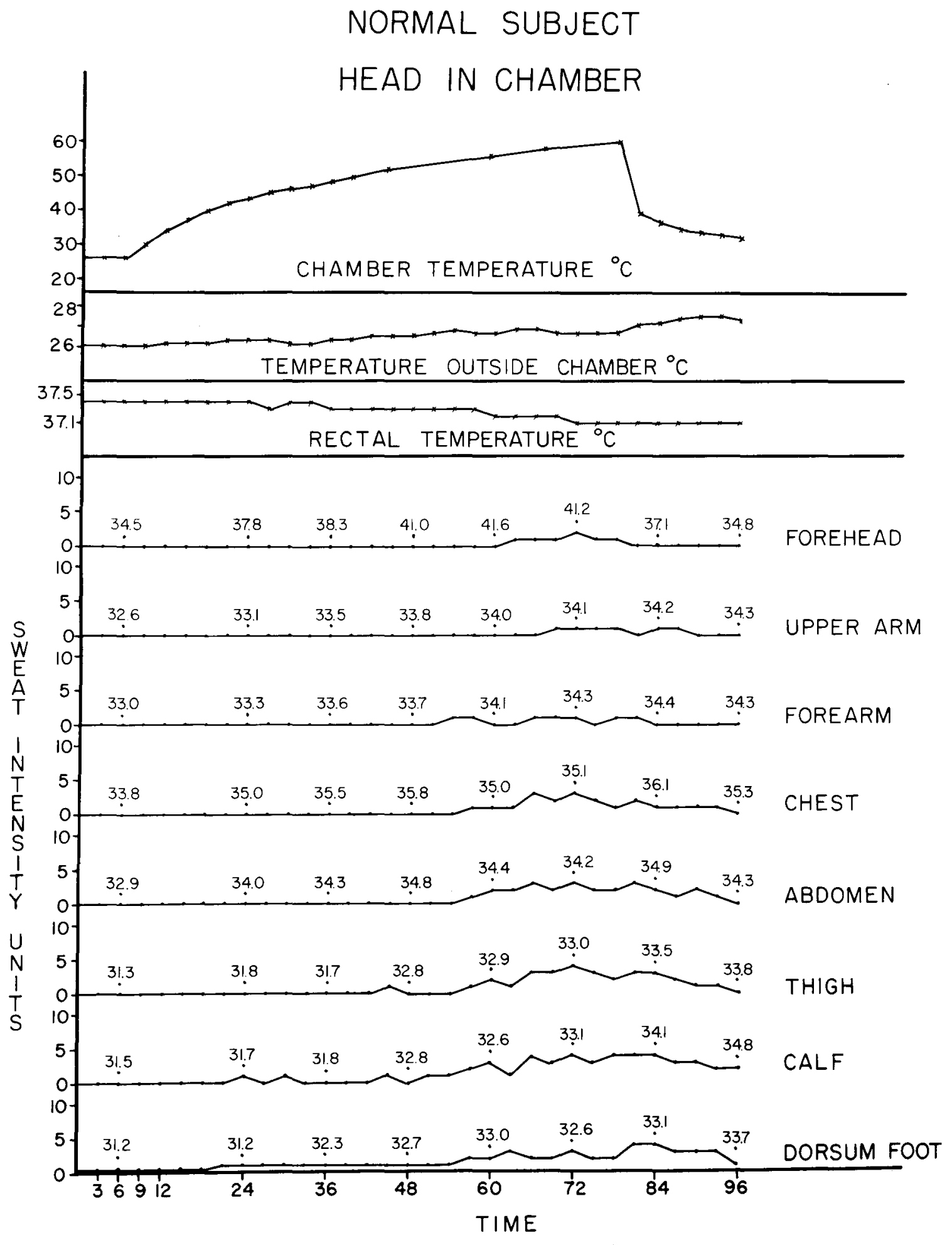

( 3 MINUTE INTERVALS)

Figure 9 


\section{NORMAL SUBJECT \\ ONE FOOT IN CHAMBER}

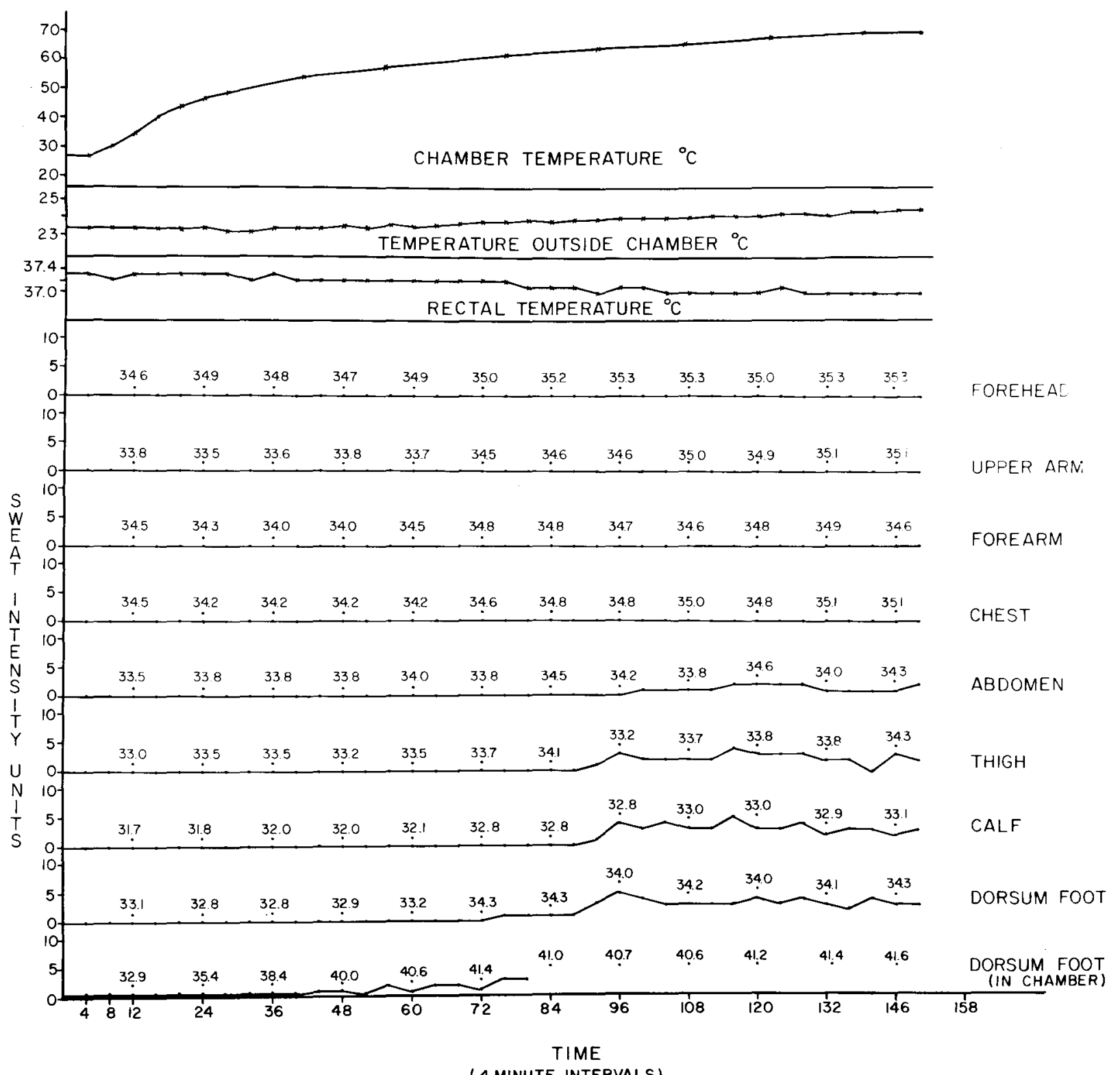

( 4 MINUTE INTERVALS)

Figure 10 
area above the abdomen. Figure 10 represents the practical limits of the experimentel procedure with regard to time and temperature. Expostare of an area to such high ambient temperatures for an appreciably longer period caused pain in the heated area and emotional sweating supervened.

A comparison of the sweating responses of the dorsum of the foot placed Inside the chamber and the dorgum of the foot outside the chamber showed that both of these areas recruited before any others. However, the doreum of the foot receiving the heat recruited first and attained higher levels of sweating than did the other foot. This is in contrast to experiments (not illustrated in this paper) in wich recordings were taken simultaneously from both feet wen they were the only areas being heated. Both feet began sweating at the same time and the patterns of their responses were almost identical.

Figure 11 represents the pattern of response when only one hand was heated In this figure, the plotted scale of response has been doubled. In no instance did recruitant asoend above the lovel of the thigh and in one subject it did not appear above the calf. Any sweating responses observed, although very definite, were of a low magnitude and were not sustained above the zero level for long periods. The experimental conditions of this study were almost identical to those of Figure 10 and both studies were conducted on the same subject.

All of the illuatrated stadies Inrolving only a portion of the body in the chamber were selected because the ambient temperetures outside the chamber were similar. This choice was made so that the total thermal stimulus required to effect the various recruitment patterns could be compared. Similar studies 


\section{NORMAL SUBJECT \\ ONE HAND IN CHAMBER}

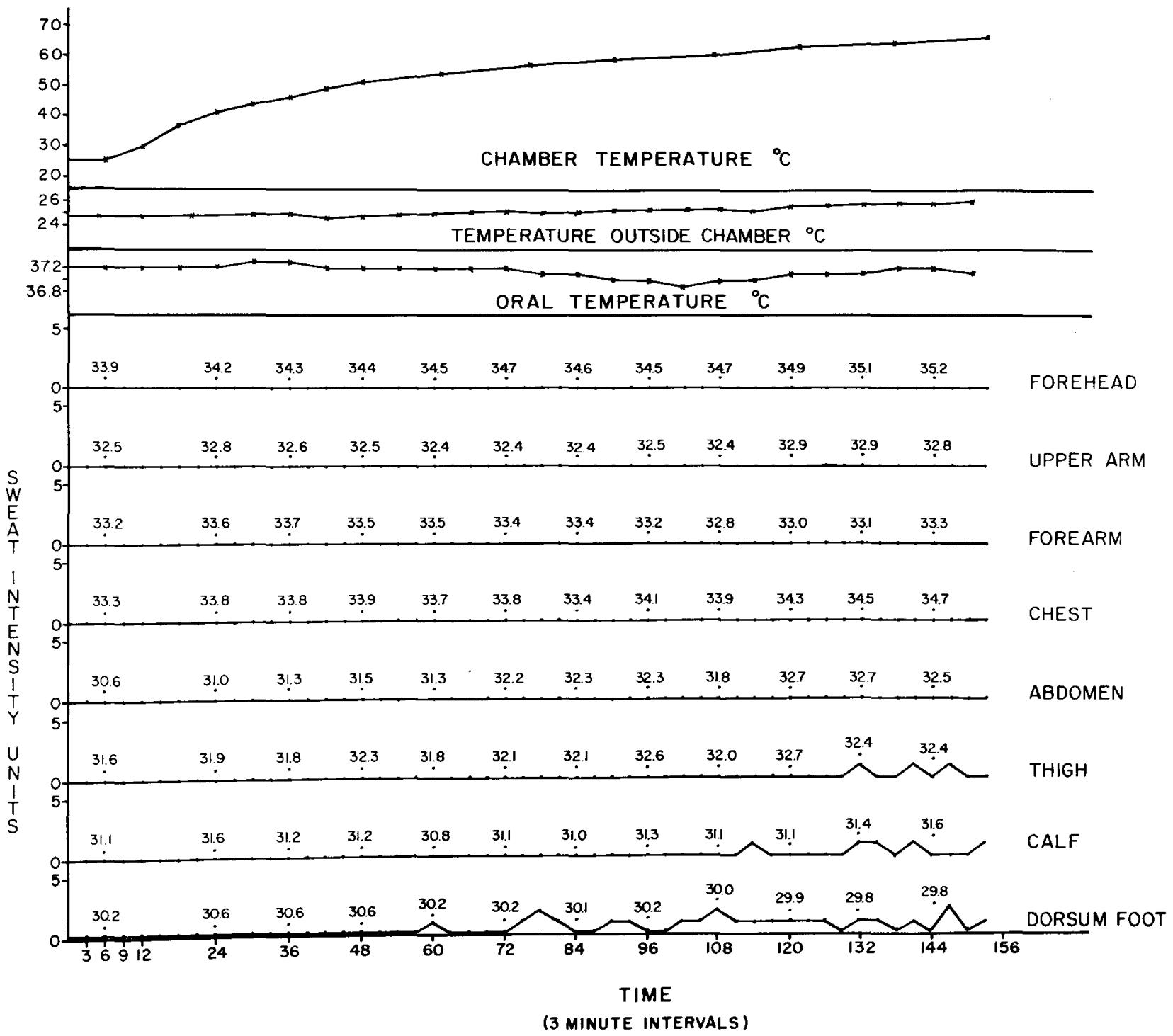

Figure 11 


\section{0}

were conducted when lower amblent temperatures existed outside the chambers the lowest being $19^{\circ} \mathrm{C}$. In none of these was there a change in the number of

areas recrulted. However, an increase was uoually observed in the time and/or the heat required to bring about recruitment. 
2. Observations on Oral and Reotal Temperatures of Normal Man during Sweat

Recruitment

Whon the entire body of normal man was heated in the chamber, recruitment of swenting generally sterted before any change in oral or rectal temperature occurred and in many instances (illustrated in Figure 4) all areas conmenced areating before these temperatures rose. An elovation in these temperatures was commonly geen after the chanber door was opened and aweating deolined or stopped.

When half of the body was exposed to heat, recrultment of swating usually started before rectel temperature rose and sometimes was eamplote before any rise occurred (Flgure 5). Hore frequently, however, body temperature chowed some elevation before all areas startad to sweat (Figure 6). These differences were not correlated with heating a partioular half of the body.

Whon lesser amounts of body surface were exposed to heat (FLgures 7, 8, 9, 10 and 11) rectal tomperature generally romained constant or fell progressively during the experinent. In the experinents illustrated in Figures 7 and 11 , the dowmard trend in deep temperatures was reversed after recruitment was well started. Even in these tudies, however, deep temperatures failed to riae above control levels. In all of the studies in wich small areas were heated, a rise in deep temperature above the control level was observed on only one occaston. 


\section{Patterns of Sweat Recruitment in Paraplegic Man}

All of the following observations were made on patients with surgically verified, anatomically complete spinal cord transections. When the entire body of the paraplegic subject was placed in the chamber and the temperature progressively elevated, sweating appeared on those areas completely removed from high center control (Figure 12). Indeed, it occurred first on the lower extremities and proceeded cepheled in the identical recruitment pattern deseribed for the normal subject. Thus, we may draw the significant conclusion that a thermal aweating reflex was modiated by segments of the spinal cord below the level of transection. Sweating on the lower areas was of relatively low intensity then compared with the normal subject (Figure 4 ). Nevertheless, the thermal spinal reflex was clear cut and sometimes reached the magnitude of a plus 4 response (Figure 3a). Figure $3 b$ is an un-retouched photograph of a plus 3 response from the dorsum of the foot of a patient with a complete lesion at T5. A comparison of Figures 4 and 12 reveals that the time and heat required to effect recruitant of aweating essentially the same for the normal and paraplegic subjects. Sweating usually started before a rise in body temperatare occurred but a rise invariably occurred before all areas were recruited.

In order to further exanine the factors responsible for the intiation of spinal reflex oweating, the paraplegic subject was studied with only the upper or lower portion of his body exposed to heat. The level of structural injury to the spinal cord was the dividing line between "in" and "out". Figure 13 represents a stady in which only thet portion of the body below the level of 


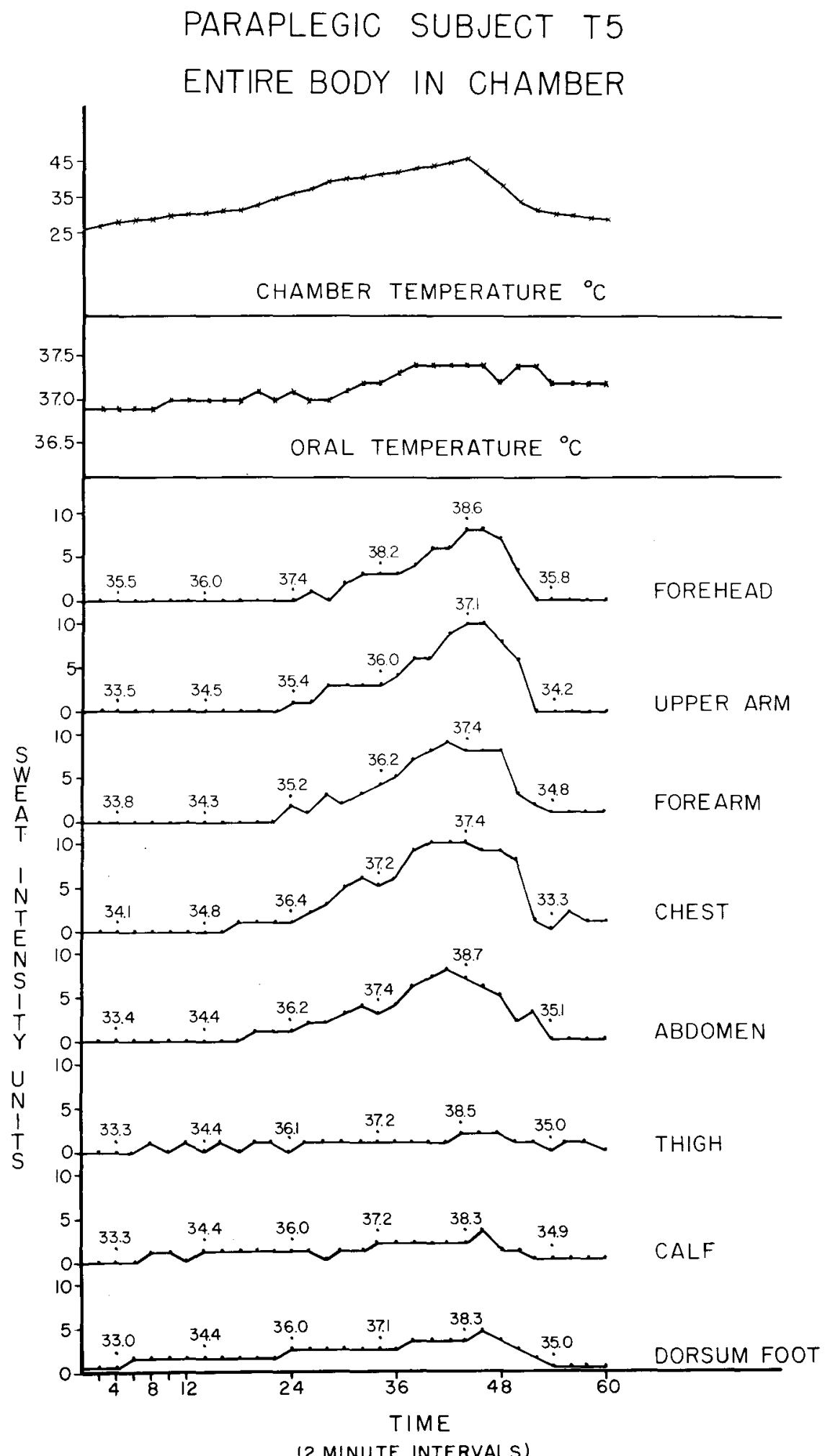

(2 MINUTE INTERVALS) 


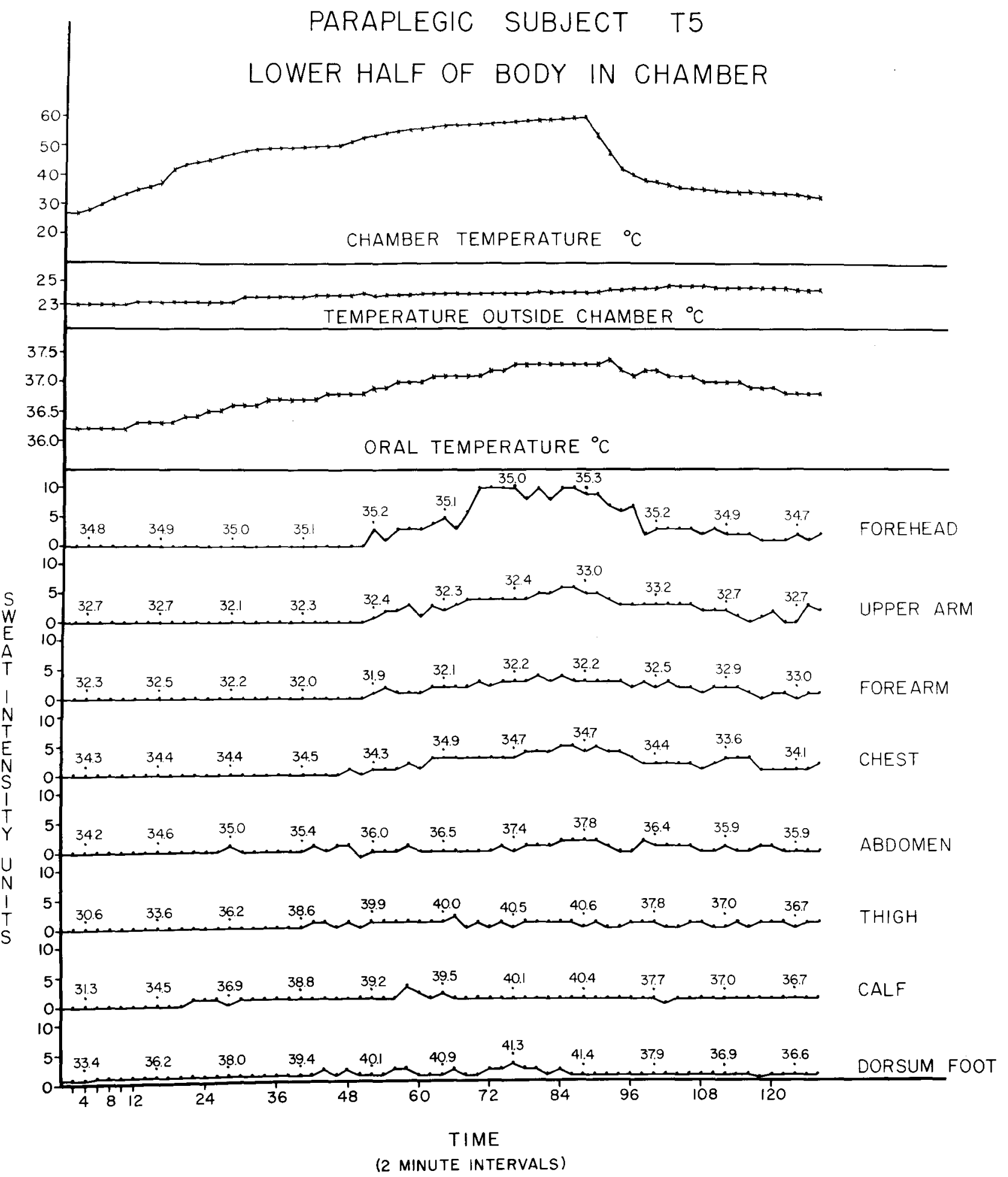

Figure 13 
the lesion was heated in the chamber. As in the normal subject (Fizure 5), heating only the lower portion of the body was oufficient to bring about recruitment of sweating on the ent1re body. Hote that the dorsum of the foot began to sweat before body temperature rise occurred, but a rise of $0.4^{\circ} \mathrm{C}$. was observed before all of the areas below the lesion exhibited a response. A rlse of over a degree in oral tomperature occurred in the latter stage of the study due undoubtedly to the low sweating responses on most areas. It is interesting that even with prolonged heating at very high temperatures and with an elevation in body temperature of over a degree centigrade, the sweats ing responses on the lower extremities still did not rise great amount above the reletively low initial rates. The normal subject with the lower portion of the body in the chamber exhibited considerably higher rates on these lower areas. However, the temperature and time relationship for recruitment of all areas was again the same as that of the normal subject.

When the paraplegic subject was reversed so that only portion of the body above the lesion we heated, the normal recruitment pattern was broken (F1gure 14). Sweating occurred first on the upper portion of the body and last on the lower extrenlties. These lower areas exhibitod a response only after prolonged heating at high environmental temperatures and only after body tomperature had risen from 0.60 to $1.00 \mathrm{C}$. When sweating did appear on the lower extremities it was in a charactorlotic recruitment pattern, that is, with the dorsun of the foot aweating first. 


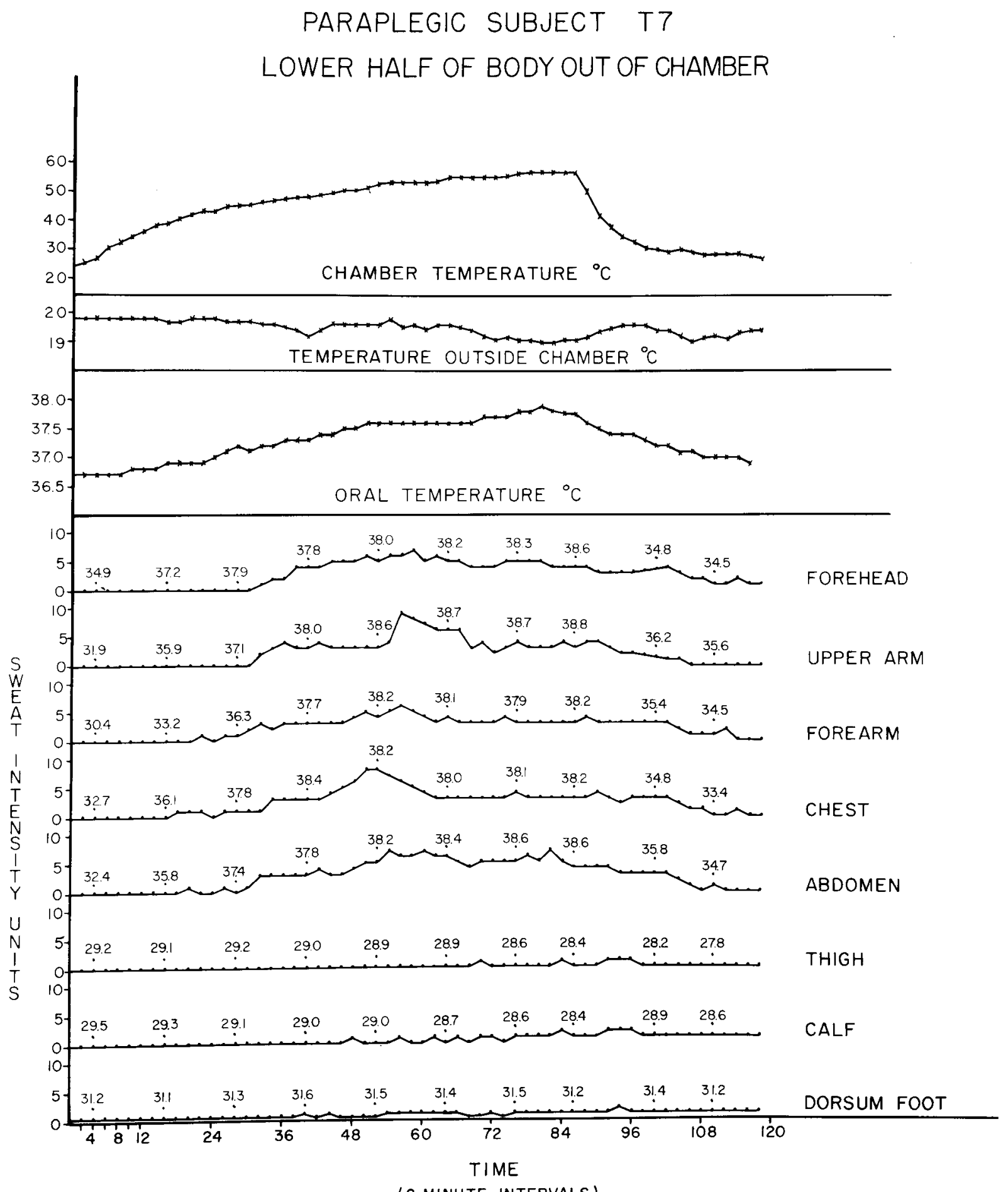

(2 MINUTE INTERVALS)

Figure 14 
4. Skin Temperatures of Hormal Man

In all experiments skin temperatures were recorded by means of thermocouples. In some experiments radiometer measurements were also taken. A comparison of date derived sinultaneously from the two methods is illustrated in Figure 15 in wich a subject was studied with the lower extremities in the chamber. Thermocouple and radiometer measurements usually agreed within $0.5^{\circ} \mathrm{C}$. until ambient temperatures exceeded $40^{\circ}-42^{\circ} \mathrm{C}$. At higher ambient temperatures deviation of $2.00 \mathrm{C}$. or more was comnonly observed between the readings of the two methods. The themocouple readings were always conaistentIy higher and undoubtodly did not correctly ropregent the skin temperatures, since the thermocouples were unshielded and were influenoed by the radiant sources in the chamber in the same way 28 the skin to which they were applied. The thermocouple date were plotted for all experiments illustrated in this report because they were more complete. At high amblent temperatures where this data was questionable, it wes employed only to interpret general directional changes in skin temperature.

When the entire body of normal man was hested in the chamber a rather rapid early rise in skin temperature occurred on all areas (Figure 4). The areas with the lowest initial temperatures exhibited the greatest percentage change (e.g. dorsur of the foot). When sweating commenced on an area, the temperature usually continued to rise but at a slower rate. It is interesting that even though the forehead exhibited the highest temperatures it was one of the last areas to sweat (Figure 4). On the other hand, the dorsum of the foot had the lowest temperatures and it was the first area to sweat. When 


\section{COMPARISON OF RADIOMETER AND THERMOCOUPLE RECORDINGS}

AREAS OUTSIDE CHAMBER

\begin{tabular}{|c|c|c|c|c|c|c|c|}
\hline AMBIENT & & 25 & & & & & -27 \\
\hline \multirow{2}{*}{ FOREHEAD } & $\mathrm{Ra}$ & 34.1 & 34.4 & 34.2 & 34.1 & 34.1 & 34.0 \\
\hline & Th & 34.4 & 34.5 & 34.4 & 34.1 & 34.2 & 34.6 \\
\hline \multirow[t]{2}{*}{ UPPER ARM } & $\mathrm{Ra}$ & 32.8 & 32.8 & 32.3 & 32.1 & 32.1 & 31.9 \\
\hline & Th & 33.0 & 32.7 & 32.2 & 32.2 & 32.0 & 32.0 \\
\hline \multirow[t]{2}{*}{ FOREARM } & $\mathrm{Ra}$ & 33.5 & 34.1 & 34.0 & 33.7 & 33.8 & 33.2 \\
\hline & Th & 33.5 & 33.9 & 33.7 & 33.9 & 34.1 & 33.1 \\
\hline \multirow[t]{2}{*}{ CHEST } & $\mathrm{Ra}$ & 34.2 & 33.5 & 33.2 & 33.3 & 33.2 & 32.6 \\
\hline & Th & 33.8 & 33.6 & 33.2 & 33.3 & 33.1 & 32.2 \\
\hline \multirow[t]{2}{*}{ ABDOMEN } & $\mathrm{Ra}$ & 33.5 & 33.9 & 33.7 & 32.5 & 32.6 & 32.4 \\
\hline & Th & 33.5 & 34.0 & 33.4 & 32.6 & 32.2 & 32.2 \\
\hline
\end{tabular}

AREAS INSIDE CHAMBER

AMBIENT ${ }^{\circ} \mathrm{C}$

THIGH

CALF

DORSUM FOOT

$\begin{array}{llll}25-30 & 35-40 & 40-42 & 42-45\end{array}$

$46-48 \quad 51-53$

\begin{tabular}{lllllll} 
& $25-30$ & $35-40$ & $40-42$ & 4245 & $46-48$ & $51-53$ \\
\hline Ra & 34.0 & 35.3 & 36.6 & 36.6 & 36.2 & 36.7 \\
\hline Th & 33.8 & 35.5 & 37.0 & 37.6 & 38.3 & 38.6 \\
\hline $\mathrm{Ra}$ & 33.3 & 35.0 & 35.8 & 36.1 & 36.1 & 36.3 \\
\hline Th & 33.6 & 35.0 & 36.2 & 36.8 & 37.5 & 38.3 \\
\hline $\mathrm{Ra}$ & 31.7 & 34.1 & 34.3 & 35.1 & 35.1 & 37.8 \\
\hline Th & 32.0 & 34.2 & 34.6 & 36.5 & 37.2 & 40.0
\end{tabular}

$\mathrm{Ra}$ - RADIOMETER READING

Th - THERMOCOUPLE READING

Figure 15 
the chamber was rapidly cooled, a precipitous drop in temperature occurred on and areas.

When only a portion of the body was heated, skin temperatures on that portion consistontly rose in a manner similar to that described above. The rise was greater, however, when the elevation of temperature wes greater and the duration of application longer (0.g. dorsum of the foot, Flgures 8 and 20 ). A different temperature pattern was characteristic of the areas outside the chamber. These areas usually showed an initial rise in temperature and If sweating occurred, leveled off or even declined. These points are well illustrated on the upper areas in Figure 5. Exception to this sometimes occurred. For example, the dorsum of the foot and the oalf in Figure 6 show a progressive decline in temperature throughout the entire pre-sweating and sweating periods.

Frequent2y, when the chamber was suddenly cooled, a rise in skin temperature was observed on areas outside the chamber after they had ceased sweating. This rise often continued at a gradual rate until the termination of the experiment (Figure 7).

Superimposed upon the long range progressive increases or decreases in the temperatures of various areas were short term periodic fluctuations. Such changes did not appear to follow a set pattern, and were observed most frequently and clearly on areas outside the chamber. The upper areas in Figure II illustrate this point. A mimute to minute analysis of these temperatures (not illustrated) revealed very gradual increases and decreases in the temperatures of these areas. 


\section{Skin Temperatures of Paraplegic Man}

When the entire body of the parapleglc subject was heated in the chamber, the skin temperature pattern was essentially the same as in the normal individual. However, the peak temperatures attained on most areas were usually higher than those exhibited by the normal individual (Figures 4 and 22 ).

In studies in which the lower portion of the paraplegic subject was in the chamber, all areas exposed to heat showed a progressive rise in temperature as did those of the normal subject (Figure 13). Most upper areas outside the chamber exhibitod a gradual rise wich on occasion tended to "level off" during the sweating phase (e.g. forearn and chest, Figure 13). The magnitude of temperature change of areas outside the chamber was not as great as in the normal subject. Also, the outside areas did not show as large a drop in temperature during the sweating phase as did comparable areas in the normal subject. A rise in temperature of outside areas was sometimes observed several mimutes after cooling the chamber. This rise usually continued until the termination of the study (e.g. chest and forearm, Figure 13).

When only the upper portion of the paraplegic subject was heated, the upper areas exhibited responses essentially the same as the normal subject except that the peak temperatures were higher (Figure 14). A progressive fall In the temperatures of the lower areas outside the chamber was observed. 


\section{DISGUSSION AND CONCLUSIONS}

The sudies on paraplegic patients were initially planned in an effort to more completely understand the phenomenon of swat reoruitment in normal man. Because several informative conclusions may be dram from these studies It seens practical to discuss them first.

The sweating responses below the level of surgically verified anatonically comple to spinal cord transections demonstrate beyond question the existence of themul spinal roflex sweating in man. This fact has not been demonstrated proviously and is in direct contrast to classical concopts. Although the response is elear and umistakable (Figure 3a) its relatively low intengity, as compared with normal, indicates that the thermal spinal reflex can ellolte a aweating response of only almited magnitude. For profuse sweating rates to occur, continuity between the spinal cord and the hypothalamus appears necessary. The sequential recruitment of sweat glands on the lowor extremities and the cyclic nature of the responses demonstrate that the isolated spinal eord is capable of iloiting the same qualitative rosponse as in the normal subfect. The essential difforenoe observed in this investigation was quantim tative.

It is probable that one or more of the following factors were primarily responsible for elloiting the thermal reflex pattorn below the lesion. First, the environmentel temperature acting directly on cutaneous receptors and/or effector organs. Second, an elevated blood tomperature warming cutaneous re- 
ceptore and/or effector organs. Third, an elevated blood temperature affectIng spinal centers. An attempt was made to resolve this problew by stadying the pareplegic subject placed half in and half out of the chamber. Application of heat to areas below the lesion induced a normal pattern of recruitment of sweating on all areas. However, when the heat was applied to areas above the lesion the normal recruitment pattern was broken. This conclusively demonstrated that thermal stimulation of cutaneous receptors and/or affector organs was required for reeruitment to occur in a normal sequential pattern. However, sweating on the lower extromities, although late, did occur. This oweating commenced only after a very significant elevation in blood temperature. In Figure 14 the lower extremities exhibitod a continuous decline in gkin temperature throughout the study. Although the location of the sensory receptors to heat is unknown, it is difficult to imagine that their temperatures increased as skin temperatares fell. This would tend to rule out the affect of blood temperature on peripheral receptors and end organs. Thus, the stimulus for response was most probably the direct action of an elevated blood temperature on spinal centers.

The fact that the lower extremities eventually sweat in a sequential pattern when only the areas above the lesion are heated is important to the nole problem of recruitment. There appears to be within the spinal cord a gradient of excitability decreasing in a caudal to cephalad direction. Some ovidence of quentitativo differences at various spinal levels of facilitation in the sudomotor pathwars has been reported (47). In the "upper half in" - tadies on paraplegic patients the external facilitating influence (blood 
toaperature) wes probably the sane at all levels of the isolated spinel cord. The apparent gradient of facilitation could therefore be explained on the basis of an inherent difference in the neuron pools within the spinal cord. Whatever the cause of this inherent difference, it appears to be reflected in a lower threshold for response. The lower threshold areas would be more easily facilitated by given stimulus regardiess of whether it was afferent drive from the periphery or an elevation in cord temperature.

The sequential recruitment of sweating in the nomal aubject could also be explained on the basis of such a postulation. Even though in many of these studies the hypothalamus was undoubtodly exerting an influence, it is difficult to imagine sequential recruitment facilitated by differential hypothalamic discharges or preferential pathways to various cord levels. It seems more reasonable that hypothalamic influence is exerted by almilar and simultanoous discharge to 211 spinal areas. If the latter were true, what appeare to be a gradient of facilitation of various spinal levels would actually be a gradient In excitability of the neuron pools within the cord.

The tudies on normal subjects that comprised heating of 9 per cent or less of the totel body surface all demonstrated complete or fractional sequential recrultment of the body. The sudomotor responses were directly related to sensory stimulation by heat. As the percentage of heated area increased, the completeness of recruitwent and/or the intensity of response incroased. Also, the responses were directiy related to the duration and intensity of heat epplication to an area. It is obvious from these atudies that the efferent drive from the periphery was exerting a facilitating in- 
fluence upon the cord. This influence could have been directly on the cord or 1ndirect through a long reflex mechanism via the hypothalamus. As for direct Influence, when only the arm is heated, it is difficult to Imagine that the lower portion of the cord responded first because there was a greater impingment of impulses on it from the periphery. It is more logical to presume that the lower cord area is more easily facilitated by a given level of afferent drive due to an inherently lower threshold for response. If the influence of afferent drive is exerted vie the hypothalamas, then it is again improbable that a differential disoharge to various cord levels occurs. Al though no direct phyoiological evidence exists demonstrating the existence of a long reflex via the hypothalame, the anatomical pathways, al though unknown, probebly do exist. The profuse projection of ascending fiber tracts into the hypothalamus make it easy to postulate the exiatence of such athway. Probably there is both direct and an indirect influence of afferent drive on the cord. The hypothalamus undoubtedly contributes to the magnitude of the aweating response. This is denonstrated by the fact that the responses obtained on the lower extremities of the normal subject when only the arm was heated were groater than those of the lower extremities of the paraplegic patient when his entire body was heated.

In these "minimal area" studies the recruitment responses during periods of falling rectel temperature minimized the posslbility of their origin in rising hypothalamic temperature. Al though rectal teraperature may not necessarily roflect hypothalamic temperature, it is unlikely that the tro temperatures would proceed in opposite directions. The thead $\mathrm{in}^{n}$ studies may 
be an exception to this.

There are several experinental demonstrations that give furthor indication thet the recruitment petterns in normal man are reflexly mediated at spinal 10vels. First, the lower extremities aterted sweating first regardless of which ares of the body was heated. Second, when both feet wore heated sweating began simultaneously on both feet. When only one foot was heated swating occurred on both feot but it appeared oarlier and reached a higher intensity on the heated side. Third, when only the upper extrenity or head was heated, and the chamber suddenly cooled, sweeting subsided quite abruptiy on most areas. Fourth, all of these phenomena occurred hen the deep temperature was at or below control levels. Also, wen the entire body was heated and then cooled, rectal temperature usually rose as sweating subsided. It is diffieult to reconcile these facts without postulating spinal mediation of thermal reflex sweating.

When 7 per cent or more of the totel body aurface of the normel subject was heated a sequential reoruitment of swouting was observed on all rogional areas. When 3.5 por cent or 108 of the body ourfact wa heatad a fractional recrultinent of the body obtained. Thus, for the experinentel conditions presonted, the minimal amount of the body ourface erea that must be heated to bring about recruitment of the entire body 11 es between 3.5 and 7 per cent of the totel surface area.

The "head in" and "arm in" studies each involved hesting about 9 per cent of the body surface area. The ease of recruitment as well as the magnitude of rosponse was consistently greater then when 7 per cent of the body area was 
heated. Also, recruitment of more areas consistentiy occurred when one foot ( 3.5 per cent) was heated than when one hand $(2.5$ per cent) was heated. Inus, a $I$ or 2 per cent reduction in total surface area heated caused a definito difference in response. An al ternative explanation for these differences could involve a significantly different concentration of afferent receptorg In the hand and foot. Since these studies were made on heated surface areas near or below the minimal neceasary to effect complete reoruitment, it is not particularly surprising to see this. Bven though 1 per cent of the total body surface is a very amall fraction of the whole, a reduction of this amount from the "one foot in" to the "one hand in" studies represented approximately a 30 per cent reduction in the area being heated. A comparison of the "head in" and "arm in" studies with the "both feet in $^{n}$ studies represented a decrease of only 2 per cent of the totel body surface area being placed in the chamber. However, it represented a reduction of over 20 per cent in the area ectually houted.

The sudden decline in sweating, observed in many of the studies when the chamber was rapidly cooled, occurred before any significant change in deep temperature ras recorded. It was most probably due to two factors. First, the withdraval of sensory stimulation by heat and the consequent decrease in afferent drive. Second, reflex central inhibition brought about through atimulation of inhibitory afferente by the cool air. The central inhibition could be caused by direct action on the cord or by indirect influence through a long reflex vis the hypothalanus. The supposition of central inhibition is supported by studies (not illustrated) in which the upper half of the body was 
heated and the chest then cooled by the application of an ice pack. Even though heat was continuously applied to the remaining upper arees, and deep temperature was not immediately altered, a dramatic cessation of sweating becurred on all areas. When this same study was repeated with the entire body In the chamber, a sudden decrease in sweating rates occurred on all areas. However, the lowermost areas continued to sweat at a reduced rate. Apparently In the lattor studies, the central inhibition was subminimal for complete depression of the afferent drive effect of heat on the lower threehold areas of the cord.

When the entire body of normal man was heated in the chember, the initial rise in skin temperature of all areas reflected primarily two phenomenas the direct heating of the skin, and (2) peripheral vasodilatation. The latter point is demonstrated by the fact that areas of nomally high vasomotor activity (o.g. the foot) showed a greater change in skin temperature than areas of normally less intense vasomotor activity (e.g. forehead). In these atudies, the tendency for skin temperature to level off when high sweating rates occurred demonstrated the direct effect of evaporative heat loss on skin temperature. When only a portion of the body was heated, the common occurrence of an initial rise in skin temperature of the non-heated areas most probably raflected. reflex peripheral vasodilatation. The "leveling off" or decline in temperature of these areas when oweating commenced, and the subsequent rise when sweating ceased, offers further demonstration of correlation between evaporative heat loss and skin temperature. The perlodic fluctaations in temperature of nonsweating areas (e.g. upper areas of the "hand in" study, Figure ll) also are 
probably indicative of raflex vamomotor activity.

It is particularly interesting that the areas with the highest initial temperatures are not the firat to sweat. Also, note that the dorsum of the foot In the "one hand in" study (Figure il) started sweating after vory little chenge In its temperature. A comparison of this evidence to the skin tomperature of the heated foot in the "one foot in" 8 tudy (Figure 10) demonstrates an important point. That is, the initiation of a sweating response on particular area Is not necessarily correlated with the temperatare of thet area.

In the studies on paraplegic subjects an essential difference from normal was noted in the skin temperature of areas below the lesion. This difference was woll demonotrated when only the areas above the lesion were heated. The lower areas showed only a decline in temperature with no periodic fluctuations. 


\section{SUMHARX}

When the entire body of norwal men is exposed to a progressive elevetion of environmontel temperature, arenting rouponses are oharacterised by consistent pettern of recruitment in which swating first oocure on the lowermost portion of the body and then proweeds cephalad to ul thrately include all reglonal areas. Thte save genaral patern of recrultent also obtatns when lessor amounts of the body axiace aren are heated. The alnimal amount of the total body aurfece that mut be hested to effect recruitsont of wil regionul areas is botwown 3.5 and 7 per cent. Fecrultwent of only the lower areas of the body occure then 3.5 per cont or 1889 is heeted. All of the swantints responses obeerved won 9 per cent or leas of the body arve is hanted occur wen rotel temperature is the asme or belou control levels. It is postulated that these responsen are reflexly medlated at oplnal lovels. The probabllity of faollitation of apinal lovels through a long reflex vis the hypotheinans is discusaed.

When the entire body of the paraplogle patient (surgioaliy verifled oomplete apinal cord tranection) Is exposed to an elevated ambient temperature, swating doos occur on those areas completely removed from hiph center control. It occure firet on the lower extremities and proceods oephaled in the normal recrultant pattern. Thus, in contrast to claseical conoepta, a thernal oneating roflex is modsated by segments of the apinal cord below the lavel of 
50

transection. The two primary causes of these spinal thermal sweating responges are most probably cutaneous sensory stimulation by heat, and increased excitability of spinal centers due to elevated blood temperature.

In normal subjects correlation is seen between the skin temperatures and cutaneous evaporative heat losses. Skin temperature changes indicative of peripheral vasomotor activity are also observed. 


\section{BIBLIDGRAPHY}

1. Ikeuchi, $K_{0}$, and Kuno, $\mathrm{I}_{\text {. }}$ On the regional differences of the perspiration on the surface of the human body. J. Orient. Hed, I; 67-89 and 106-7, 1927.

2. Burch, O. E., and Sodeman, W. A. Regional relationships of rate of water loas in normal adult in sub-tropical elimate. Ax. J. Physiol., $138: 603,1943$.

3. Weiner, J. S. The regional distribution of sweating. J. Physiol., 10l4: $32-40,1945$.

4. Hortsman, A. B., Randall, W. C., Poiss, C. N., and Seckondorf, R. Regional rates of evaporation from the skin at various environmental temperatures. J. Appl. Physiol., 5: 153-61, 1952.

5. Hermann, F., Prose, P. H., and Sulzberger, W. B. Studies on sweating. V. Stadies of quantity and distribution of thermogenic aweat delivery to the skin. J. Invest. Dermat., 18; 71-86, 1952.

6. Randall, W. C., Hortrman, A. B., and Ederstrom, H. E. Dermatomal recruitwent of aweating in response to heat. Fed. Proc., 10: 103104, 1951 (No. 1).

7. Randall, W. C., and Hertzman, A. B. Studies on cutaneous heat losses. III. The dermatomal recruitment of swenting in response to generalized radiant hesting. A. F. Technical Report Ho. 6680, 13 pp., December, 1951.

8. Randall, W. C., and Hertamen, A. B. The dermatomal recrultment of sweating in response to generalized radiant henting. J. Appl. Physiol., 5. 399-409, 1953.

9. Randall, W. C., Peiss, C. H., and kawson, R. O. Simul taneous recruitmont of sweating and percoption of warmth in man. J. Appl. Physiol. 12: $385-89,1958$.

10. Kuno, Y. The Physiology of Human Perspiration. London: J. and $A$. Churchin Ltd., 1934.

11. Sdolph, E. F. The initiation of sweating in response to heat. Am. J. Phyriol., 145: 710-15, 1946. 
12. Ranson, S. W., Fisher, C., and Ingram, W. R. Hypothalamic regalation of temperature in the monkey. Arch. Meurol, and Psychlat, 38 : $445-66,1937$.

13. Ranson, S. W. The hypothelamus as a therrastat regulating body teraperature. Psychosom. Hed., 1, 486-95, 1939.

14. Clark, G., Magoun, H. W., and Ranson, S. W. Hypothalamic regulation of body temperature. J. Neurophysiol., 2, 6I-80, 1939.

15. Magoun, H. W., Harrison, F., Brobeck, J. R., and Ranson, S. W. Activation of heat loss mechaniams by local heating of the brain. $J$. Nourophysiol. I: 101-14, 1938.

16. Davison, C., and Selby, N. E. Hypothermia in cases of hypo thalamic lesions. Arch. Heurol. and Psychiat., 33: 570-91, 1935.

17. Davison, C. Disturbances of temperature regulation in man. Assoc. for Research Nerv. and Mont. Dis. 20: 774-823, 1940.

18. Erickson, T. C. Neurogenic hyper thermia. Brain, 62: 172-90, 1939.

19. Zimnerman, H. M. Temperature disturbances and the hypothalamus. Assoc. for Research Nerv. and Ment. Dis. 20: $824-40,1940$.

20. Isist, C. F. and Peet, M. M. Sweat secretion of man. V. Disturbances of sweat secretion with lesions of the pons, medulia and cervical portion of the cord. Arch. Neurol. and Psychiat., 42: 1098-1127, 1939.

21. Beaton, L. E., and Leninger, C. K. Spinal distribution of the thermoreguletory pathways in the monkey. J. Neurophys 101., 6: 37-38, 2943.

22. Roth, G. H., Johnson, D. A., and Craig, W. McK. Physiologio effect of anterolateral chordotomy in man. J. Appl. Physiol., 5t 261-66, 1952.

23. Bazett, H. C. Theory of reflex controls to explain regulation of body temperature at rest and during exercise. J. Appl. Physiol. 4 : $254-62,1951$.

24. Sinclair, D. C., Weddell, G., and Zander, E. The relationship of cutaneous and sensibility to neurohistology in the human pinna. J. Anat., 86: 402-11, 1952 . 
25. Hagen, E., Knoche, H., Sincleir, D. C., and Weddell, G. The role of spocialized nerve terminais in cutaneous sensibility. Proc. Roy. Soc., London, .. B147: 279-87, 1953.

26. Lele, P. P., weddell, G., and williams, C. M. The relationship between heat transfor, skin temperature and outaneous sensibility. J. physiol., 126: 206-33, 1954.

27. Randall, W. C. Reflex sweating responses and the influence of arterial occlusion upon sweat gland activity. Fed. Proc. 6: 183-84, 1947.

28. Randall, W. C., Deering, R., and Dougherty, J. Reflex sweating and the inhibition of sweating by prolonged arterial occlusion. J. Appl. Physiol., 1: 53-59, 1948 .

29. Iseluts, B., Hetenyi, G., and Doisy, A. The physiology of sweet secretion. Arch. Intern. Pharmacodynamio, 83, 133-42, 1950.

30. Kuno, Y. Human Perspiration. Springfiold, III.: C. C. Thomas Co.. 1956.

31. Evans, C. L. Principles of Human Physiology. Philadelphia: Lea and Febiger, 1952.

32. Rothman, S. Physiology and Biochemistry of the Skin. Chicago: Univ. of Chicago Press, 1954.

33. Fulton, J.F. Textbook of Phyaiology. Philadelphia: W. B. Saunders and Co., 1954.

34. Head, H., and Riddoch, G. The automatic bladder, excessive sweating and some other reflex conditions, in gross injuries of the spinal cord. Brain, 40: 188-263, 1917 .

35. List, C. F., and Pimenta, A. D. Swat secretion in mant Spinal reflex awating. Arch. Nourol. and Paychiat., 51: 501-507, 1944.

36. Gilliet, R. W., Guttman, L., and Whittoridge, J. Inspiratory vasoconstriction in patients after spinal injuries. J. Physiol., 197: $67-88,1948$.

37. Pyzik, S. W. Defects in the regulatory mechanisms of autonomic function in injuries to the spinal cord. Proc. Clin, Paraplegia Conf. 5: $78-80,1956$. 
38. Pollock, L. J., Boshos, B., Chor, H., Finkelman, J., Arleff, A. J., and Brom, M. Defects in regulatory mechanisms of autonomic functions in injuries to the spinal cord. J. Neuruphysiol., 14: 85-93, 1951.

39. Cuttman, L. Ein neues oinfaches Colorimetrisches Verfahren zur Untersuchung der Schweissdmsenfunktion. KIIn. Wschr. 16: 212-13, 1937.

40. Minor, $V_{0}:$ Eines neues Verfahren zu dor blinischen Untersuchung der Schwissabsonderung, Deutsche Ztschr. f. Nervenh. 101: 302-08, 1927.

4I. Riddoch, G. The reflex functions of the completely divided epinal cord in man, compared with those associatod with less severe lesions. Brain, 40: 264-402, 1917.

42. Guttman, $L_{0}$, and Whitteridge, D. W. Effects of bladder distension on autonomic mechanisms after spinal cord injuriea. Brain, 70, $361-404,1947$.

43. Randell, W. C. Sweat gland activity and changing patterns of aweat secretion on the skin surface. Am. J. Physiol. 147. 391-98, 1946.

44. Hardy, J. D. and StoII, A. M. Radiometric measurement of skin temperaturea. Kethods in Medical Research, Vol. 6, Chicago t Year Book Publishers, 1954.

45. Foerster, 0 . Die Symptomatologie der Schussverletzungen der peripheren Nerven, Handb. f. Nourol., 1485, 1929.

46. DuBois, D., and DuBois, E. F. Clinical Calorimetry. The measurement of surface arva of man. Arch. Int. Med., 15: 868, 1915.

47. Thomes, P. E., and Korr, I. M. Significance of areas of low electrical akin resistance. Fed. Proc. 11: 162, 1952. 
APPROVAL SHEET

The dissertation submitted by Russell C. Seckendorf has been read and approved by five members of the faculty of the Graduate School. The final copies have been examined by the director of the dissertation and the signature which appears below verifies the fact that any necessary changes have been incorporated, and that the dissertaion is now given final approval with reference to content, form, and mechanical accuracy.

The dissertation is therefore accepted in partial fulfillment of the requirement for the Degree of Doctor of Philosophy.
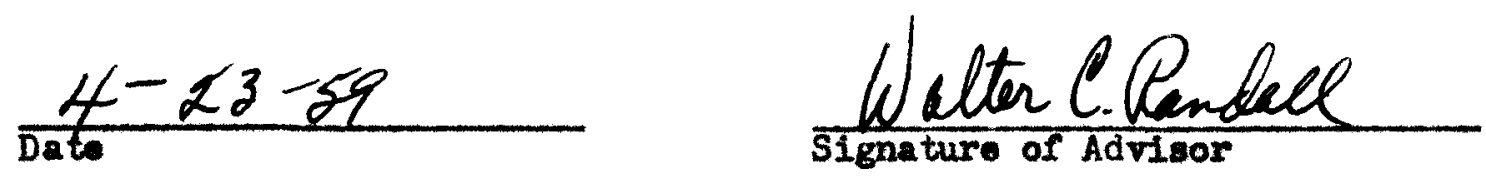